Brit. J. soc. Med. (1947), 1, 149-181

\title{
THE RELATION OF MORBIDITY TO AGE IN AN ARMY POPULATION
}

\author{
BY \\ LANCELOT HOGBEN, F.R.S. \\ Consultant in Army Medical Statistics \\ AND \\ MURIEL M. JOHNSTONE, M.A., Ph.D. \\ Junior Commander, A.T.S. \\ (Received April 1, 1946)
}

\section{INTRODUCTION}

Public health statistics provide a wealth of material with reference to the relation of age to mortality risk from individual diseases; and it has long been customary to adjust mortality rates by means of appropriate standardizing factors to forestall erroneous comparisons of crude deaths in populations of different age structure. Within the framework of private practice, civilian medicine provides no comparable opportunities for an exact study of the relation of age to risk of contracting diseases, other than such as are certifiable to public health authorities or such as are speedily fatal. Indeed current medical treatises and articles abound with figures for proportions of cases examined in different age groups cited as an indication of the liability of individuals to contract a particular disease in a given age group. It should be-but is not in fact-needless to remark that this procedure is highly misleading. . Naturally, the physician meets very few cases of peptic ulcer among males between the ages of 95 and 99 inclusive, for the simple reason that there are in fact very few males alive at that age. The practice of putting on record such case-age distributions, in contradistinction to age-incidence distributions exhibiting frequency of onset related to the appropriate population at risk at a given time of life, is a counsel of despair consequent upon the difficulty of delimiting the population from which a civil hospital draws its patients, and hence of defining the relevant demographic data for drawing correct conclusions.

Correct information of this sort is of value both because it may furnish clues for an attack on the nature of the ageing process, and because it is a prerequisite of medical man-power planning in a society with a swiftly-changing age-composition. The Army, with an all-in system of social medicineand a complete population. census, therefore offers a unique opportunity for studying the relation of age to 
morbidity risks. To be sure, it has the disadvantage that it can provide no information with respect to the oldest and youngest age groups; and it is a selected population. However, any community subject to large-scale emigration and immigration is a selected population in the same sense, if not to the same extent; and in total war the selectivity of the recruitment machinery is minimal. It is a fact to which we should give due weight; but it is by no means such as to make the resources of Army statistics valueless to medical science in this context. With this end in view they supply two classes of documentary material respectively relating to
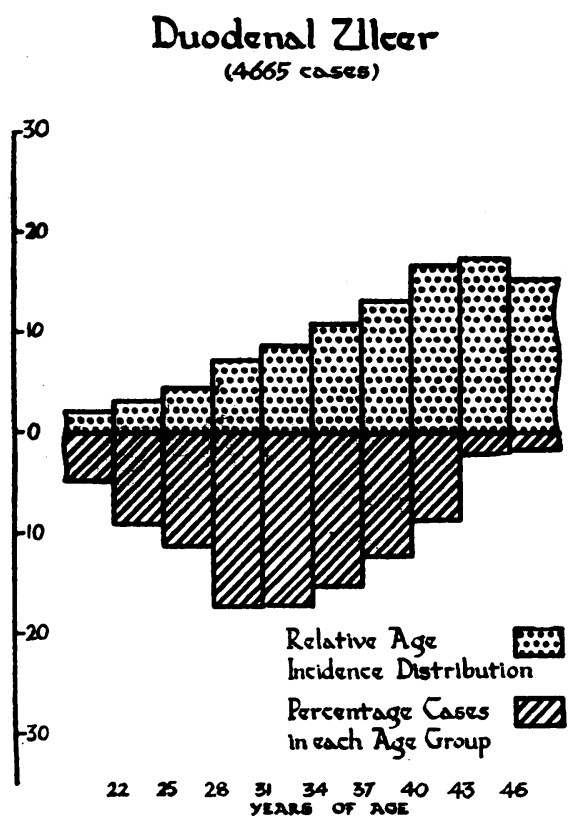

\section{$\underset{(636 \text { cases) }}{\underset{\text { Anxiety }}{\text { State }}}$}

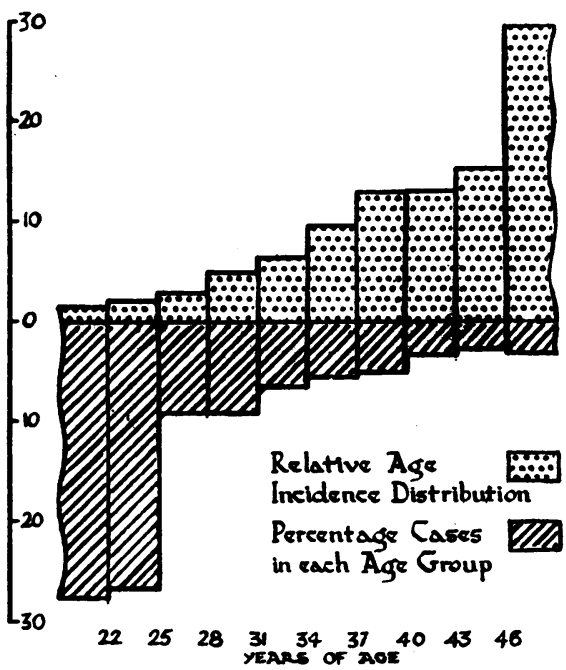

Fio. 1.- Comparison of percentage case distributions (below base line) with relative age-incidence distributions (above base line) of medical discharges for duodenal ulcer (4,665 male cases) shown on the left, and anxiety state (636 female cases) shown on the right.

discharge from the service on medical grounds (Army Form B.3978), and to hospitalization (the hospital record card Army Form I.1220). These documents share a merit which does not pertain to civilian certifications of infections or deaths, inasmuch as the diagnosis recorded thereon, in contradistinction to diagnosis on documents relating to "forward" medical units, is that of a specialist. Such are the sources of what follows.

In view of prevalent confusion between case-age distributions (proportions of cases examined in different age groups) and age-incidence distributions, which truly record risk of onset at different ages, it is pertinent to cite at the outset two examples (Fig. 1) which emphasize how grossly lack of due consideration of 
differences with reference to population at risk in different age groups may distort judgments based on clinical impressions gained from examination of patients.

\section{Agr Distributions based on SAMpling}

An age-incidence distribution, as here defined, is a specification of age-specific rates for successive age groups. In what follows $I_{x}$ stands for the specific rate of the $x$ th age group, i.e. the ratio of all cases of a condition in that age group during a given period to the contemporary population at risk in the same age group. S(. . .) stands for summation of items of the class specified within the brackets. For graphical representation of age incidence distributions of different diseases, it is advantageous to reduce all histograms to the same area. If $T_{i}=S\left(I_{x}\right)$ stands for the total of successive values. of $I_{x}$ over the entire age range, we accordingly define a ratio $R_{x}$ which satisfies this requirement, i.e.

$$
R_{x}=100 I_{x} \div T_{i} ; \text { and } S\left(R_{x}\right)=100
$$

The representation of an age distribution in this way has a further advantage. Owing to loss of documents through enemy action or circumstances related to the exigencies of .war, the total records of cases from a given theatre in a given period available for this enquiry are inevitably defective, though not in such a way as to bias the proportion of individuals assigned to a given age-group. If we do not know the exact number of cases of a disease in a population, we cannot compute the absolute age-specific rate $I_{x}$; but we can estimate the relative age-specific rate $R_{\mathbf{x}}$ if we know the age structure of the population, and the proportions of cases in each age group of an unbiassed sample of cases. This is evident from the following considerations. Let $p_{x}$ be the proportion of the population in the age group $x, \mathrm{P}_{\mathrm{x}}$ the actual number of individuals therein; $\mathrm{C}_{\mathrm{x}}$ the corresponding number of cases of a disease, $c_{x}$ the corresponding proportion which we can estimate by sampling, $T_{p}$ the total size of the population in all age groups, and $T_{c}$ the total number of cases. Thus $p_{x}=P_{x} \div T_{p}$ and $c_{x}=C_{x} \div T_{c}$. By definition we then have:

$$
I_{x}=C_{x} \div P_{x}=c_{x} \cdot T_{c} \div p_{x} \cdot T_{p}=\left(c_{x} \div p_{x}\right) \cdot\left(T_{c} \div T_{p}\right)
$$

If we denote the ratio $\left(c_{x} \div p_{x}\right)$ by $q_{x}$ and by $T_{q}$ the summation of this ratio over the complete age range,

$$
R_{x}=100 I_{x} \div S\left(I_{x}\right)=100 q_{x} \div T_{q}
$$

Since we can estimate $q_{x}$ by sampling, we can also estimate $R_{x}$ without recourse to a complete census of cases such as we require for the determination of $I_{x}$. Needless to say, the ratio $R_{x}$ like $q_{x}$ and $I_{x}$ is not additive, i.e. $R_{x+y} \neq R_{x}+R_{y}$. Distributions of this sort are therefore comparable only if based on the same classification with respect to age.

The distribution defined by $R_{x}$ suffices for the calculation of age-standardization factors in conformity with the usual procedure. If $I_{s}$ and $I_{c}$ respectively stand for the standardized and crude incidence of a disease, we define the standardizing factor $F$ as such that $I_{s}=F$. $I_{c}$ or $F=I_{s} \div I_{c}$. If ${ }_{s} p_{x}$ and ${ }_{c} p_{x}$ are corresponding 
proportions of individuals of age group $x$ in the standard and actual populations at risk,

$$
\begin{aligned}
I_{s} & =S . \quad\left({ }_{s} p_{x} \cdot I_{x}\right) ; I_{c}=S\left({ }_{c} p_{x} \cdot I_{x}\right) \\
F & =S . \quad\left({ }_{s} p_{x} \cdot I_{x}\right) \div S\left({ }_{c} p_{x} \cdot I_{x}\right) \\
& =S . \quad\left({ }_{s} p_{x} \cdot 100 \cdot I_{x} \div T_{i}\right) \div S\left({ }_{c} p_{x} \cdot 100: I_{x} \div T_{i}\right) \\
& =S . \quad\left({ }_{s} p_{x} \cdot R_{x}\right) \div S\left({ }_{c} p_{x} \cdot R_{x}\right)
\end{aligned}
$$

The indices $I_{x}, q_{x}$ and $R_{x}$ are connected by the relation:

That is to say:

$$
\frac{\Delta I_{\mathbf{x}}}{I_{\mathbf{x}}}=\frac{\Delta \mathbf{q}_{\mathbf{x}}}{\mathbf{q}_{\mathbf{x}}}=\frac{\Delta \mathbf{R}_{\mathbf{x}}}{\mathbf{R}_{\mathbf{x}}}
$$

This means that:

$$
\Delta \log I_{x}=\Delta \log q_{x}=\Delta \log R_{x} .
$$

(a) for one and the same distribution corresponding successive values of $R_{x}$, $q_{x}$ and $I_{x}$ are in the same proportions;

(b) with respect to distributions referable to different morbid conditions corresponding logarithmic increments or decrements of the three indices are in the same proportion.

The index $q_{x}$ which we have used to compute $R_{x}$ is equivalent to the ratio of the absolute specific rate of the age group $x$ to the overall incidence $\left(I_{c}\right)$ with respect to all age groups, since $I_{c}=T_{c} \div T_{p}$ and $q_{x}=c_{x} \div p_{x}=\left(C_{x} \div T_{c}\right) \div\left(P_{x} \div T_{p}\right)$. It follows that $c_{x}=p_{x}$ and $I_{x}=I_{t}$ when $q_{x}=1$. In other words $q_{x}$ is unity when: (a) the proportion of cases in a given age group is the same as the proportion of the population at risk in the same age group; $(b)$ the incidence of the condition in the given age group is identical with its overall incidence. Thus values of $q_{x}$ greater or less than unity respectively indicate a disproportionately high or low incidence in the age group concerned. When $q_{x}=1, R_{x}=100 T_{q}^{-1}=Q$; and in general any value of $q_{x}$ is obtainable by multiplying the corresponding value of $R_{x}$ by the reciprocal of $Q$, so defined. Our present aim has been comparative, i.e. to exhibit age incidence distributions in such a way as to make explicit the trend of risk with respect to different diseases as age advances. For that purpose $R_{x}$ is preferable to $q_{x}$. If the end in view is to ascertain whether a given age group contains a disproportionately high incidence of a particular condition our standard is $Q$, and values of $R_{x}$ greater or less than $\mathrm{Q}$ signify respectively a disproportionately high or low incidence in the age group. Accordingly, we also give below values of $Q$ for the distributions cited. Corresponding $\mathrm{q}_{\mathrm{x}}$ distributions are obtainable by using the reciprocal of $Q$ as a conversion factor.

Variance of $R_{x}$ - As defined above $R_{x}=100\left(c_{x} \div p_{x}\right) \div S .\left(c_{x} \div p_{x}\right)$, and hence is the ratio of two quantities each involving $c_{x}$ with sampling variance $V\left(c_{x}\right)$. The distribution of a quotient involving two quantities each liable to sampling error is not necessarily normal, ${ }^{*}$ and the derivation of an appropriate expression for its

* Geary, $\dot{R}$. C. (1930) J. roy. Stat. Soc., 93, 442.. (The Frequency Distribution of the Quotient of two Normal Variates.) Fieller, E. C. (1932) Biometrika, 24, 428. (The Distribution of the Index in a Normal Bivariate Population.) Nicholson, C. (1941) Biometrika, 32, 16. (A Geometrical Analysis of the Frequency Distribution of the Ratio between two Variables.) 
variance is intricate; but in this context it seems legitimate to short-circuit difficulties which arise in the treatment of the general case. For the quantity defined by $q_{x}=c_{x} \div p_{x}$, in which the denominator is based on an exact population census, $c_{x}$ alone is subject to sampling error, and the sampling variance of the ratio is given by:

$$
\mathrm{V}\left(\mathrm{q}_{\mathrm{x}}\right)=\mathrm{p}_{\mathrm{x}}^{-2} \cdot \mathrm{V}\left(\mathrm{c}_{\mathrm{x}}\right) \cdot=\mathrm{q}_{\mathrm{x}}^{2}\left(1-\mathrm{c}_{\mathrm{x}}\right) \div \mathrm{T}_{\mathrm{c}} \cdot \mathrm{c}_{\mathrm{x}}
$$

If we are concerned solely with comparison of relative liability to one and the same disease in different age groups, the only effect of dividing successive values of $q_{x}$ by the sum $T_{q}=S .\left(q_{x}\right)$ is to change the scale, so that the distributions $q_{x}$ for any disease are made isometric, successive values of $R_{x}$ being in precisely the same ratio as corresponding values of $q_{x}$, and hence also the sampling errors of the same sets. It would therefore appear that we can then treat $T_{q}$ as a constant, so that:

$$
\begin{aligned}
V\left(R_{x}\right) & =\frac{100^{2}}{T_{q}^{2}} \cdot V\left(q_{x}\right) \\
& =R_{x}^{2} \cdot\left(1-c_{x}\right) \div T_{c} \cdot c_{x}
\end{aligned}
$$

\section{Relation of Age to Duration of Hospitalization}

If a disease is normally treated in hospital, the patient's age at admission thereto provides the raw material of one class of data relevant to the delimitation of relative incidence $\left(R_{x}\right)$, at onset, i.e. the case-age distribution $\left(c_{x}\right)$. Our most reliable basic demographic data (vide infra) for assessing age risks refer to discharges on medical grounds rather than to hospitalization; and the age incidence distributions of such involve the relation of age to a certain level of severity as well as (or in contradistinction) to onset as such. Thus we are not entitled to expect a one to one relation between age-incidence distributions of discharges and hospital admissions unless the disease is such as would invariably and quickly lead to discharge from the service on medical grounds; and we have to entertain the possibility that administrative considerations relevant to the service prospects of younger or older patients may assign a different criterion of severity sufficient to justify the findings of a medical board. A wholly satisfactory yardstick of severity is not available. From a statistical viewpoint the only one which is generally applicable in this context is duration of stay in hospital. To the extent that we are entitled to rely on it, we have some means of deciding how far discrepancies between age distributions of discharges from the service and hospital admissions arise from the intrinsic relation of age to the gravity of a disease and its extrinsic relation to administrative policy vis $\grave{a}$ vis what degree of severity entitles the individual to release from service.

Hollerith tabulations of A.Fs. I.1220 provide us with a breakdown of diseases among Middle East troops (1943-4) by age and duration of stay in military hospitals. The figures cited below do not include stay in convalescent depot and are therefore not comparable with those used to assess total man-day wastage. They also suffer from a deficiency in so far as they do not include the entire period of 


\section{TABLE I}

Average Duration of Stay in Hospital (days) by Age; Male Other Ranks; Middle East; 1944

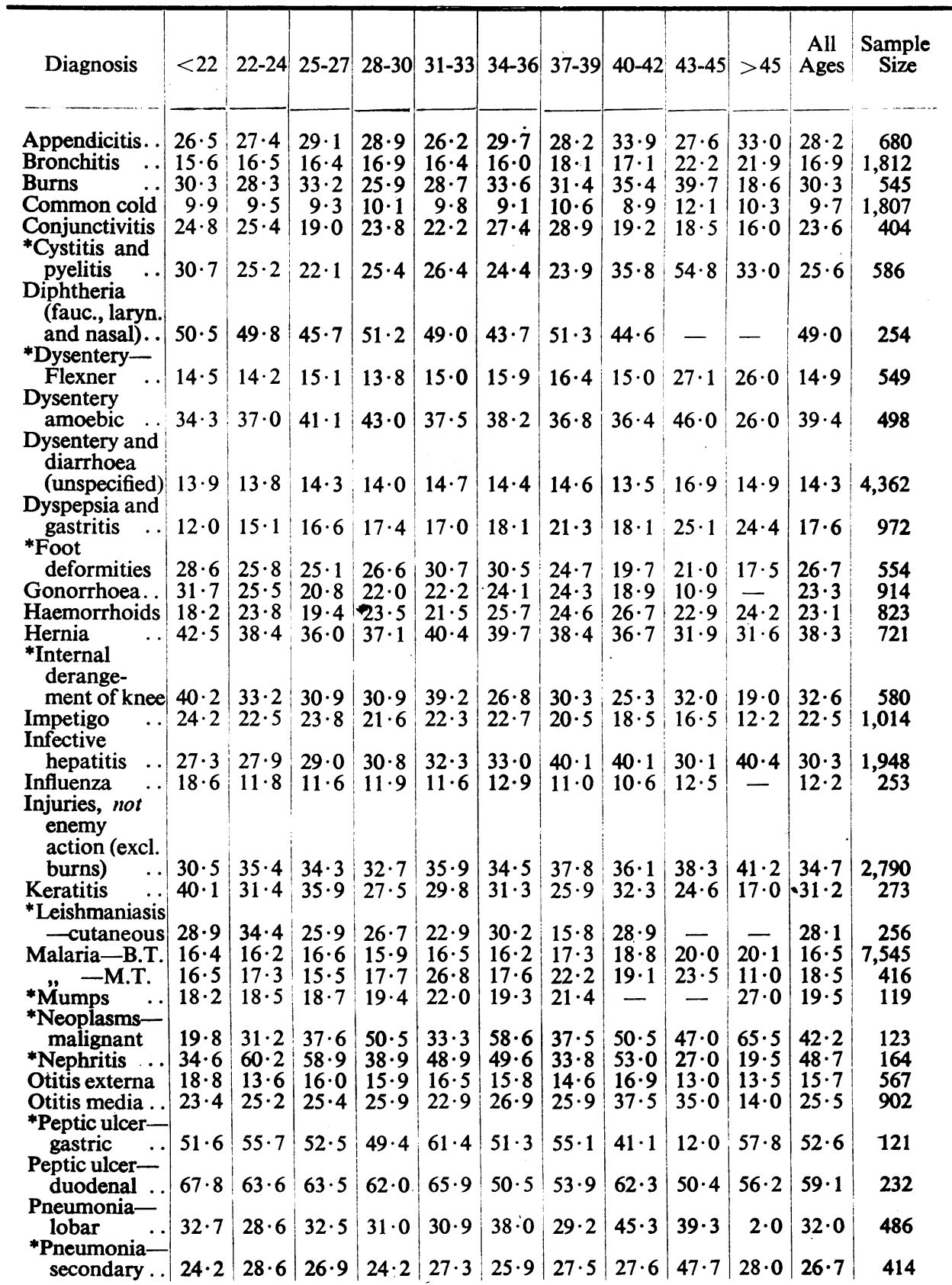


RELATION OF MORBIDITY TO AGE IN AN ARMY POPULATION 155

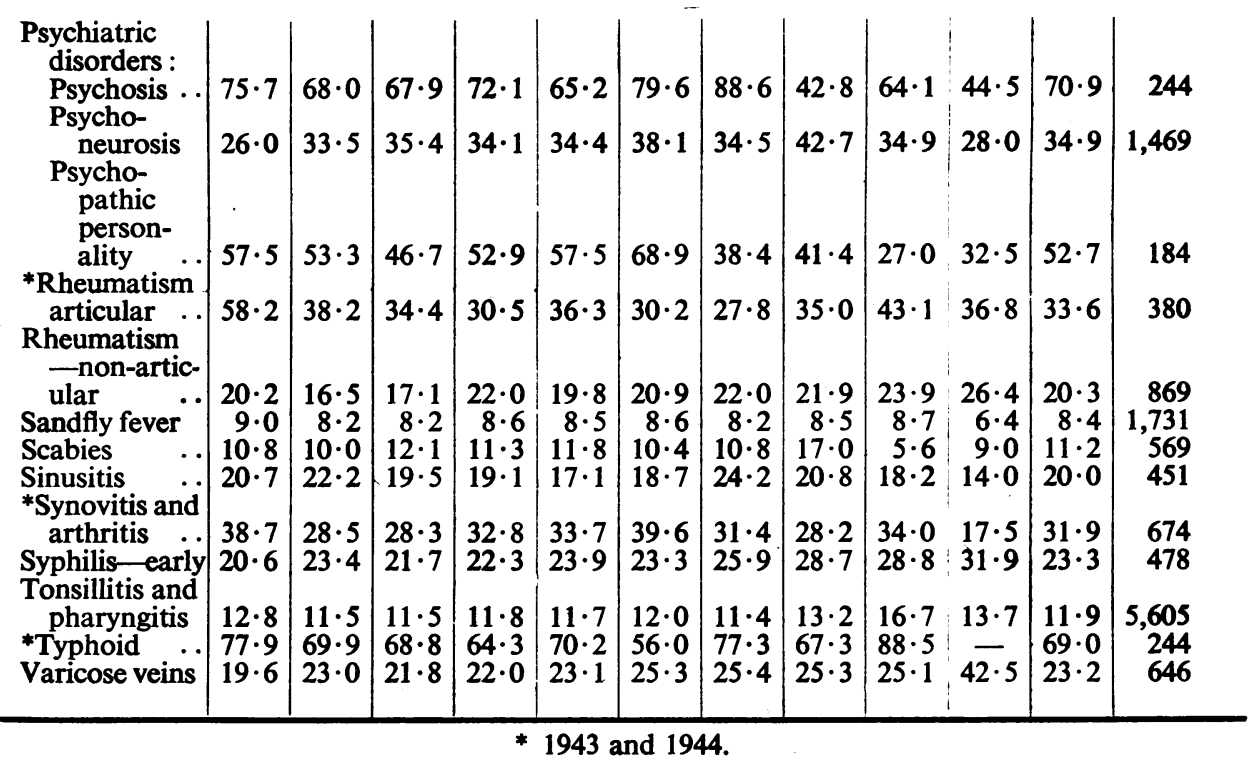

hospitalization of a small proportion of extremely serious cases evacuated from the theatre.

It is admissible that duration of stay is a crude yardstick of the gravity of a disease, but there is little doubt about the conclusions to which its use leads us, if we have to rely on it as the best tool at our disposal. The results in Tables I and II refer only to diseases of which samples sufficiently large to yield statistically clear-cut evidence are available; and they are sufficiently clear-cut to admit of little dubiety. With few exceptions, relative rates for successive age groups shown on a percentage scale in Table II do not depart widely from the $10 \%$ level. That is to say, age of the patient does not conspicuously influence the duration of stay in hospital. The exceptions to this rule are: (a) diseases (e.g. impetigo) for which we do not have to rely on data referable to discharge from service; (b) conditions (e.g. I.D.K.) which are not singular clinical entities; (c) diseases (e.g. malignant neoplasms) which either lead to speedy discharge or to death after prolonged treatment in hospital.

\section{Relation of Age to Medical Discharge}

Discharge from the Army on medical grounds takes place on the recommendation of medical boards sitting only in the United Kingdom, and the relevant documentary data refer to the whole Army. Hence data with respect to medical discharges are referable to a population whose precise age composition we know. Large samples are not available with respect to some hospitalized diseases, more particularly communicable conditions from which the patient normally makes a good recovery. Even when large samples of both are in fact available, we are not 
TABLE II

Relative Duration of Stay in Hospital by Age; Male Other Ranks; Middle East; 1944

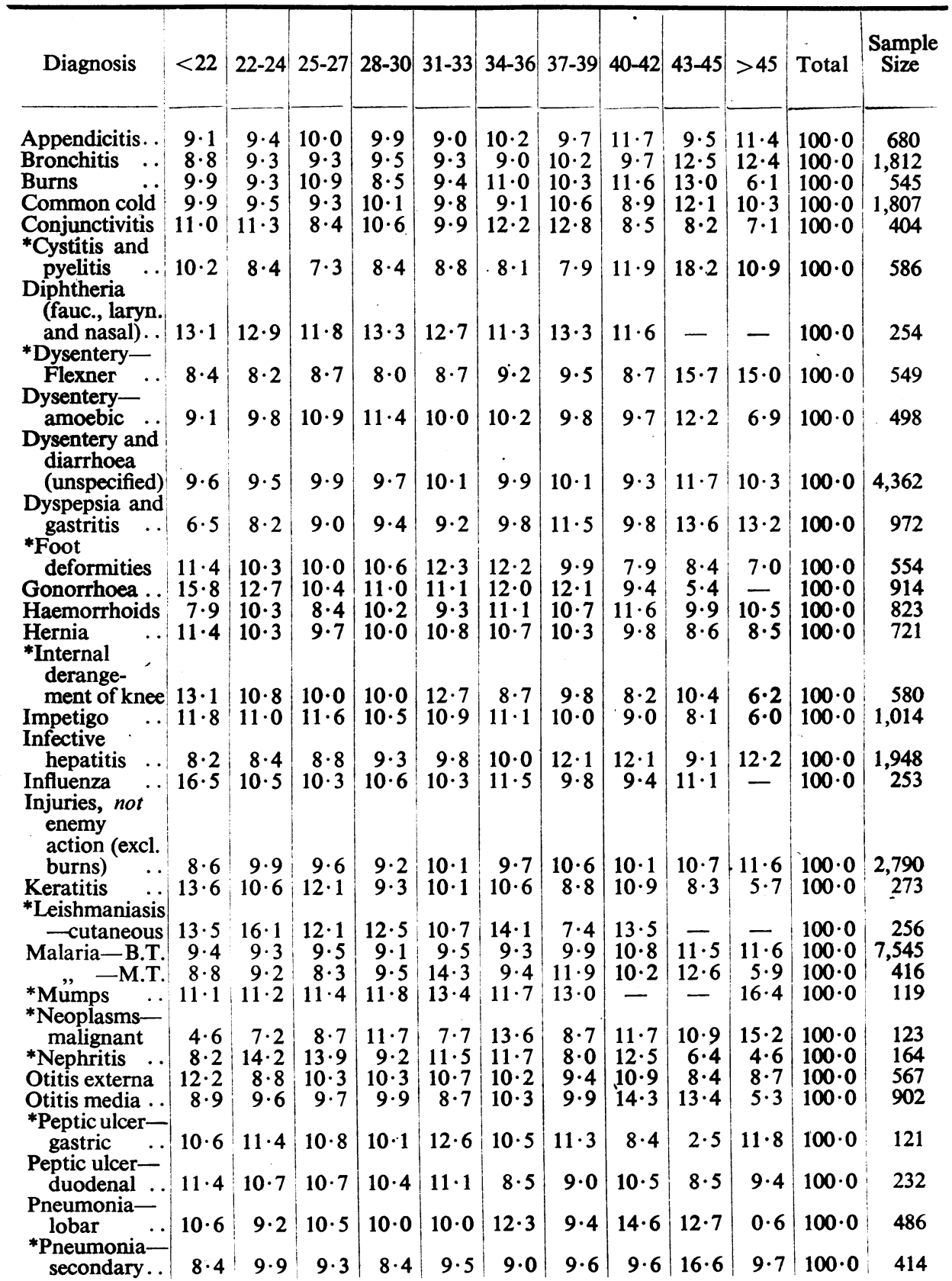


RELATION OF MORBIDITY TO AGE IN AN ARMY POPULATION.157

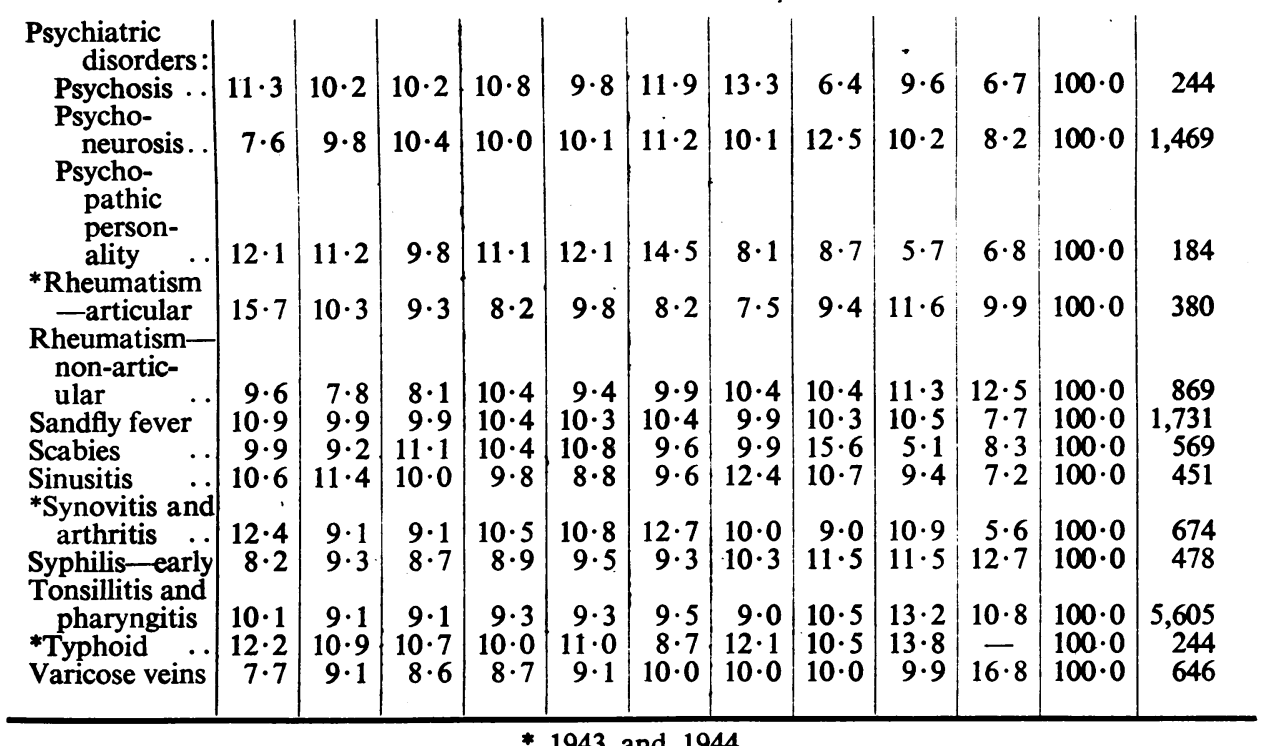

* 1943 and 1944.

necessarily entitled to assume that discharge and hospitalization data are comparable. It is therefore necessary to be explicit about when such an assumption is permissible. If a disease sufficiently severe to incur hospitalization is also sufficiently severe to incur medical discharge, age distributions based on the two sources of material should tally. When this is not true, they may fail to do so for either or both of two reasons: (a) a level of severity sufficient to incur discharge may itself be a function of age; $(b)$ administrative considerations relevant to the utilization of man-power at different ages may influence criteria of severity adopted by a medical board.

Data set forth in this section refer to diseases collectively responsible for about $75 \%$ of all discharges from the Army on medical grounds during the years 1943 alone, or 1943 and 1944 together. With two significant exceptions, schizophrenia and tuberculosis, diseases with a fairly clear-cut differential diagnosis show a characteristic trend, with a peak at the latter end of the age range, as is notably true of chronic bronchitis, peptic ulcer, malignant neoplasms, dyspepsia and gastritis, diabetes mellitus, sciatica, manic depressive psychosis, and anxiety state (Fig. 2). For purposes of comparison our list also includes several conditions of diverse aetiology or uncertain differential diagnosis, more especially psychopathic personality, I.D.K. (internal derangement of knee), V.D.H. (valvular disease of the heart), and foot deformities. Otitis media appears among diseases listed because it ranks high as a reason for medical discharge from the service; but the distribution based thereon is not strictly comparable with a distribution based on all hospital admissions. The bulk of cases recommended for discharge from the Army are chronic. We might therefore expect the age-incidence distribution of 
such cases to correspend with that of hospital admissions for chronic cases only. This is not so. Whereas the incidence of hospitalized cases of chronic otitis media is about the same in all age groups, discharge rates rise steadily with advancing age. How far the difference is due to greater gravity of the disease as age advances, and how far to greater readiness of medical boards to recommend for discharge chronic cases of long standing in the older age groups, is uncertain. A high relative specific rate for epilepsy in the youngest age group is almost certainly in large measure attributable to a high concentration of recent enlistments therein and has little or no biological significance. The higher incidence of schizophrenia in the younger age groups, and of manic depressive psychosis (Fig. 3) in the older, is in
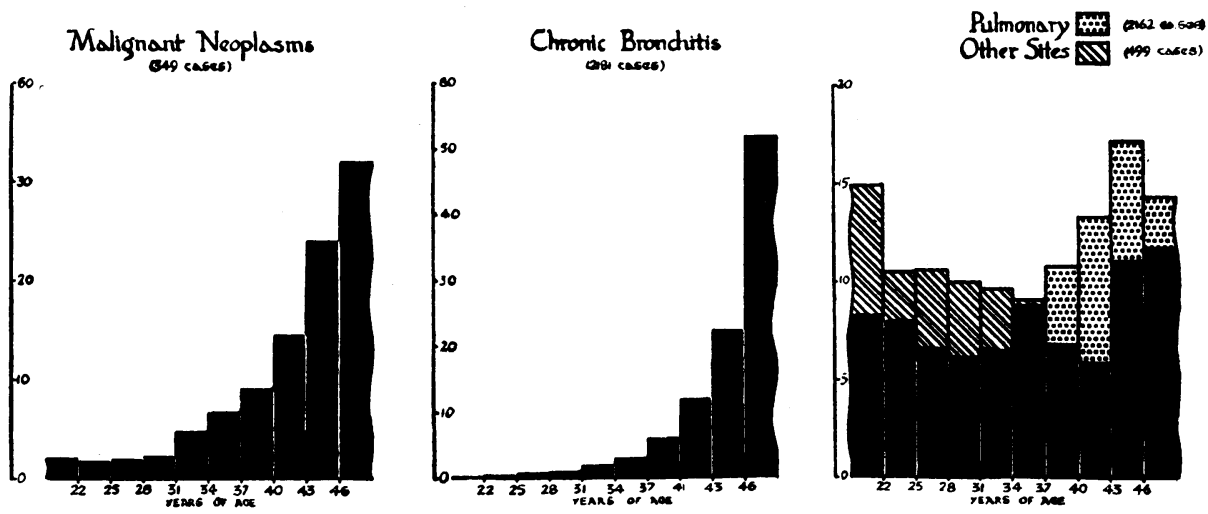

Fig. 2.-Relative age-incidence distributions of (a) malignant neoplasms (349 cases), (b) chronic bronchitis $(2,181$ cases), and (c) tuberculosis based on medical discharges of male other ranks. The figure on the right shows superimposed histograms based on 2,162 cases of pulmonary and 499 cases of tuberculosis at other sites. The overlapping portions are black, excess of pulmonary tuberculosis dotted, and excess of tuberculosis at other sites shaded.

concord with general knowledge; and since these conditions commonly incur discharge from service when recognized as such, we may regard the distribution cited as a representative picture of the relation of age to incidence. This is conspicuously true of peptic ulcers. Superimposed histograms of discharge distributions with respect to duodenal and gastric ulcer (extreme right of Fig. 4) present a picture which tallies closely with comparison of distribution based on hospitalization data (vide infra), confirming a general clinical impression that: (a) the age of onset of duodenal ulcer is somewhat earlier than that of gastric ulcer; $(b)$ whereas the incidence of the latter increases steeply over the whole age group, that of duodenal ulcer has its peak in the quinquennium 40-45, declining thereafter.

Broadly speaking, age incidence distributions for males (Table III) and females (Table IV) tally closely. Two differences call for comment. One is a relative excess of female discharges with respect to manic depressive psychosis and anxiety state in the menopausal age group. The other invites comparison with statistics. 
of the civil population. Among women (auxiliaries), age variation with respect to the discharge rate for pulmonary tuberculosis is in accordance with the general

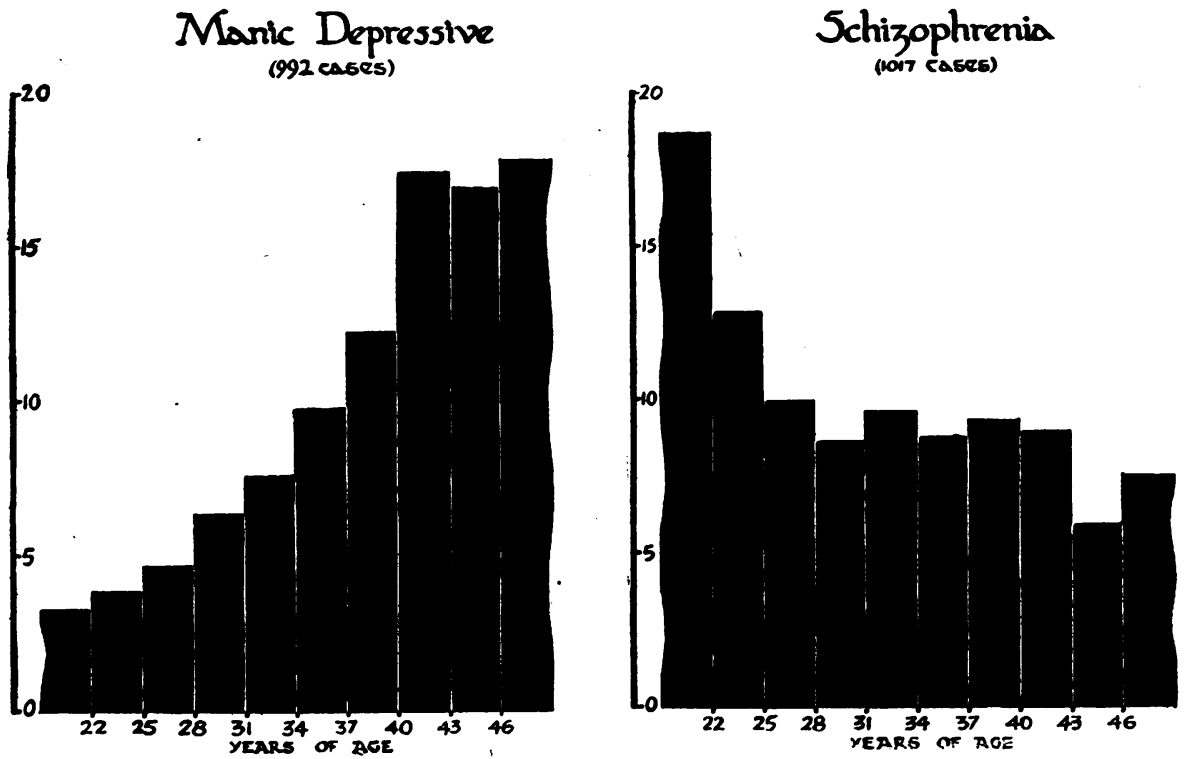

Fig. 3.-Relative age-incidence distributions based on medical discharges of the two major psychoses, manic-depressive (992 male cases) on the left, and schizophrenia (1,017 male cases) on the right.
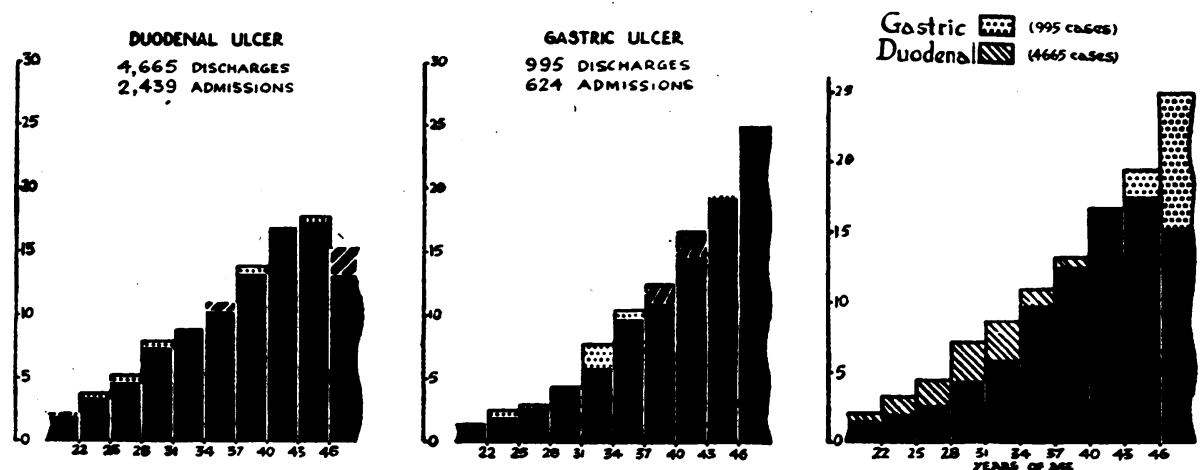

Fig. 4.-Relative age-incidence distributions of peptic ulcers. Duodenal (left) and gastric (centre). Histograms based on medical discharges and on hospital admissions superimposed with overlapping regions black, excess of discharges shaded, and excess of hospital admissions dotted. Right, superimposed histograms of gastric and duodenal ulcer, both based on medical discharges, overlapping regions black, excess of gastric ulcer dotted, and excess of duodenal ulcer shaded.

rule for infectious diseases. The younger are most affected. The distribution among males, on the other hand, shows a significant secondary rise after the age of 33 , a 
contrast which is reinforced by the exclusion from both samples of cases of pleurisy with effusion. This is in keeping with mortality figures for England and Wales

TABLE III

Relative Age-Incidence Distributions of Discharges from the Army on Medical Grounds; Male Other Rafiks

\begin{tabular}{|c|c|c|c|c|c|c|c|c|c|c|c|c|c|}
\hline & $<22$ & $22-24$ & $25-27$ & $28-30$ & $31-33$ & $34-36$ & 37-39 & $40-42$ & 43-45 & $>45$ & Total & $\begin{array}{c}\text { Sample } \\
\text { Size }\end{array}$ & \\
\hline & & & & & & & & & & & & & \\
\hline & & & & & $\begin{array}{l}2 \cdot 07 \\
8 \cdot 10\end{array}$ & $\begin{array}{r}2 \cdot 98 \\
10 \cdot 22\end{array}$ & $\begin{array}{r}5.83 \\
10.66\end{array}$ & $\left|\begin{array}{l}12.01 \\
14.72\end{array}\right|$ & $\begin{array}{l}22.45 \\
16.95\end{array}$ & $\begin{array}{l}1 \cdot 97 \\
6 \cdot 45\end{array}$ & & & \\
\hline ulcer & & & & & 5.90 & 9.75 & 12 & $\begin{array}{l}14 \\
16\end{array}$ & & & & 543 & \\
\hline & & & & & 8 & 10.96 & & & & & & & \\
\hline -all & 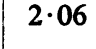 & & & & 8.12 & $10 \cdot 62$ & 13 & & & & 10 & 5,8 & \\
\hline & 0.8 & 1.0 & $2 \cdot 11$ & $2 \cdot 77$ & 3.91 & $5 \cdot 66$ & $8 \cdot 81$ & $12 \cdot 16$ & 2 & 42.55 & 10 & 487 & \\
\hline Otit & 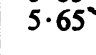 & & & & 0 & $9 \cdot 46$ & 8 & 12 & & & & & \\
\hline & $8 \cdot 8$ & 8.02 & $7 \cdot 72$ & $6 \cdot 80$ & $6 \cdot 70$ & $8 \cdot 26$ & $9 \cdot 56$ & 11 & 16 & 17 & & & \\
\hline${ }^{*} \mathrm{~T} . \mathrm{T}$ & $11 \cdot 2$ & $.8 \cdot 70$ & 8.03 & 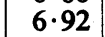 & 6. & $7 \cdot 8$ & 9. & 10 & & & & & \\
\hline${ }^{*} \mathrm{~T} . \mathrm{I}$ & $16 \cdot 1$ & $10 \cdot 27$ & $10 \cdot 40$ & 10.09 & $8 \cdot 12$ & $8 \cdot 52$ & $8 \cdot 72$ & & & & & 968 & \\
\hline *T.F & $11 \cdot 8$ & 8. & 8.37 & $7 \cdot 30$ & 6.88 & $7 \cdot 5$ & $8 \cdot 97$ & 10 & 14 & 15 & 10 & 6,681 & \\
\hline $\begin{array}{c}\text { Neor } \\
\text { me }\end{array}$ & $2 \cdot 06$ & $1 \cdot 73$ & 1.99 & $2 \cdot 31$ & $4 \cdot 81$ & $6 \cdot 75$ & $9 \cdot 23$ & 14.61 & $24 \cdot 20$ & $32 \cdot 32$ & $100 \cdot 00$ & 349 & \\
\hline Neop & & & & & & & & & & & & & \\
\hline .. & $3 \cdot 87$ & $3 \cdot 76$ & $\cdot 47$ & $\cdot 27$ & $3 \cdot 16$ & $8 \cdot 25$ & $9 \cdot 60$ & $14 \cdot 60$ & 18.69 & $26 \cdot 32$ & $100 \cdot 00$ & 100 & \\
\hline & $9 \cdot 67$ & $7 \cdot 70$ & 6 & $7 \cdot 18$ & 8.04 & $8 \cdot 53$ & 2 & $13 \cdot 81$ & 1 & 12 & & 7 & \\
\hline ties & $3 \cdot 2$ & 2 & 3 & 5 & $7 \cdot 91$ & 11.00 & 1 & 1 & & & & & \\
\hline Nepl & $5 \cdot 9$ & 4 . & & & $6 \cdot 71$ & 5.92 & & & & & & & \\
\hline $\begin{array}{l}\text { *Hern } \\
\text { *Inter }\end{array}$ & $0 \cdot 3$ & 0.3 & 0 . & 1 & 1.67 & $2 \cdot 91$ & 5 & 10 & $14 \cdot 56$ & 63 & 10 & 36 & \\
\hline rangement of & $3 \cdot 69$ & $5 \cdot 58$ & $8 \cdot 16$ & $9 \cdot 62$ & $11 \cdot 51$ & 11.60 & 12.54 & 12.03 & $10 \cdot 65$ & $14 \cdot 60$ & $100 \cdot 00$ & 431 & \\
\hline $\begin{array}{c}{ }^{*} \text { Diabetes } \\
\text { mellitus }\end{array}$ & 5 & $5 \cdot 66$ & $\cdot 31$ & $6 \cdot 11$ & $4 \cdot 94$ & $7 \cdot 41$ & $7 \cdot 67$ & $11 \cdot 57$ & $\mid 17 \cdot 17$ & $28 \cdot 15$ & $100 \cdot 00$ & 507 & \\
\hline $\begin{array}{l}{ }^{*} \text { Diss } \\
\text { scle }\end{array}$ & $4 \cdot 1$ & $5 \cdot$ & & $0^{\circ}$ & 2.93 & $11^{\circ}$ & 9. & & & & & & \\
\hline Sciat & 1.41 & 1.90 & & $3 \cdot 42$ & 5.95 & 7.96 & $12 \cdot 44$ & & & & & 413 & \\
\hline${ }^{*}$ Epil & $21 \cdot 50$ & $10 \cdot 40$ & $8 \cdot 87$ & 8. & $8 \cdot 70$ & $8 \cdot 74$ & 8.99 & & & & & 2,224 & \\
\hline $\begin{array}{l}\text { Ment } \\
\text { Anxie }\end{array}$ & $\begin{array}{r}14 \cdot 73 \\
2 \cdot 91\end{array}$ & $\begin{array}{l}6 \cdot 1 \\
3 \cdot\end{array}$ & 5. & $\begin{array}{l}5 \cdot 84 \\
5 \cdot 71\end{array}$ & $\begin{array}{l}5 \cdot 88 \\
7 \cdot 11\end{array}$ & $\begin{array}{l}7 \cdot 86 \\
9 \cdot 09\end{array}$ & $\begin{array}{r}9.58 \\
11.04\end{array}$ & \begin{tabular}{|l|}
$15 \cdot 18$ \\
$16 \cdot 00$
\end{tabular} & \begin{tabular}{|l|}
$14 \cdot 96$ \\
$19 \cdot 33$
\end{tabular} & $\begin{array}{l}14 \cdot 16 \\
20 \cdot 70\end{array}$ & $\begin{array}{l}100 \cdot 00 \\
100 \cdot 00\end{array}$ & $\begin{array}{l}1,098 \\
6,325\end{array}$ & \\
\hline P:yc & & & & & & & & & & & & & \\
\hline sive & 12 & $8 \cdot 21$ & $7 \cdot 70$ & $8 \cdot 23$ & $7 \cdot$ & 8 & 8 & 27 & $5 \cdot 45$ & $11 \cdot 28$ & $100 \cdot 00$ & 2,774 & \\
\hline & $3 \cdot 2$ & 3. & $4 \cdot 68$ & 6. & $7 \cdot 6$ & 9. & 12 & 17 & 16 & 17 & & 992 & \\
\hline & & & & & $8 \cdot$ & 9. & & & & & & & \\
\hline & $18 \cdot$ & $12 \cdot 8$ & 1. & & $9 \cdot($ & $8 \cdot 79$ & & & & & & 1,017 & \\
\hline $\begin{array}{l}\text { *Paranoid state } \\
\text { Obsessional stat }\end{array}$ & $\begin{array}{l}0 \cdot 21 \\
4 \cdot 41\end{array}$ & $\begin{array}{l}1 \cdot 16 \\
5 \cdot 89\end{array}$ & $\begin{array}{l}1 \cdot 25 \\
8 \cdot 32\end{array}$ & $\begin{array}{l}4 \cdot 72 \\
8 \cdot 14\end{array}$ & $\begin{array}{l}4 \cdot 19 \\
8 \cdot 24\end{array}$ & $\begin{array}{l}5 \cdot 66 \\
7.96\end{array}$ & $\begin{array}{l}11 \cdot 18 \\
15 \cdot 32\end{array}$ & \begin{tabular}{|l|}
$14 \cdot 23$ \\
$12 \cdot 95$
\end{tabular} & $\begin{array}{l}31 \cdot 94 \\
21 \cdot 30\end{array}$ & $\begin{array}{r}25 \cdot 45 \\
7 \cdot 47\end{array}$ & $\begin{array}{l}100 \cdot 00 \\
100 \cdot 00\end{array}$ & 140 & \\
\hline & & & & & & & & & & & & & \\
\hline
\end{tabular}

* Sample includes 1944 cases.

which show age distributions with a peak in middle life some 20 years eaflier for females than for males. Within the age-range.of the Army population, therefore, civilian mortality experience tallies with the results exhibited in Tables III and IV. 
Further available evidence ${ }^{1}$ suggests that excess pulmonary tuberculosis among males of middle life is caused by the additional industrial risks to which they are subject.

TABLE IV

Relative Age-Incidence Distributions of Discharges from the Army on Medical Grounds; Females (A.T.S. AUXILIARIES)

\begin{tabular}{|c|c|c|c|c|c|c|c|c|c|c|c|}
\hline & $<22$ & $22-24$ & $25-27$ & $28-30$ & $31-33$ & $34-36$ & $37-39$ & $>39$ & Total & $\left|\begin{array}{c}\text { Sample } \\
\text { Size }\end{array}\right|$ & $\mathbf{Q}$ \\
\hline $\begin{array}{l}\text {-chronic.. } \\
\text { ers-all } \\
\text { onary (exci. }\end{array}$ & $\begin{array}{l}1 . \\
4\end{array}$ & $\begin{array}{l}1 \cdot 76 \\
3 \cdot 73\end{array}$ & $\begin{array}{l}4 \cdot 00 \\
5 \cdot 39\end{array}$ & $\begin{array}{r}4.96 \\
15.04\end{array}$ & $\begin{array}{r}11 \cdot 96 \\
7 \cdot 20\end{array}$ & $\begin{array}{r}6 \cdot 25 \\
10 \cdot 54\end{array}$ & \begin{tabular}{|l|}
$23 \cdot 99$ \\
$28 \cdot 32$
\end{tabular} & \begin{tabular}{|l|}
$45 \cdot 32$ \\
$25 \cdot 49$
\end{tabular} & & $\begin{array}{l}135 \\
129\end{array}$ & $\begin{array}{l}3 \cdot 40 \\
5 \cdot 48\end{array}$ \\
\hline 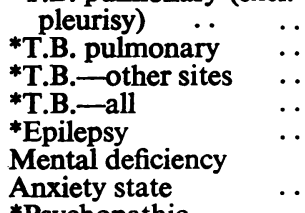 & $\begin{array}{r}19 \cdot 42 \\
20 \cdot 00 \\
17 \cdot 26 \\
19 \cdot 33 \\
27 \cdot 39 \\
11 \cdot 43 \\
2 \cdot 80\end{array}$ & $\begin{array}{r}16 \cdot 93 \\
17 \cdot 30 \\
13 \cdot 57 \\
16 \cdot 41 \\
17 \cdot 98 \\
6 \cdot 68 \\
3 \cdot 90\end{array}$ & $\begin{array}{r}17 \cdot 50 \\
18 \cdot 17 \\
13 \cdot 17 \\
17 \cdot 01 \\
15 \cdot 22 \\
5 \cdot 43 \\
5 \cdot 14\end{array}$ & $\begin{array}{r}16 \cdot 63 \\
13 \cdot 30 \\
15 \cdot 77 \\
13 \cdot 83 \\
14 \cdot 18 \\
14 \cdot 03 \\
8 \cdot 84\end{array}$ & $\begin{array}{r}10 \cdot 76 \\
10 \cdot 59 \\
18 \cdot 09 \\
12 \cdot 28 \\
5 \cdot 41 \\
16 \cdot 55 \\
11 \cdot 14\end{array}$ & $\begin{array}{l}13 \cdot 15 \\
11 \cdot 29 \\
22 \cdot 13 \\
13 \cdot 74 \\
19 \cdot 82 \\
23 \cdot 81 \\
16 \cdot 47\end{array}$ & $\begin{array}{c}3 \cdot 30 \\
2 \cdot 52 \\
-\overline{1 \cdot 94} \\
\overline{7 \cdot 08} \\
22 \cdot 38\end{array}$ & $\begin{array}{c}2 \cdot 31 \\
6 \cdot 82 \\
\overline{5 \cdot 44} \\
\overline{15 \cdot 00} \\
29 \cdot 34\end{array}$ & $\begin{array}{l}100 \cdot 00 \\
100 \cdot 00 \\
100 \cdot 00 \\
100 \cdot 00 \\
100 \cdot 00 \\
100 \cdot 00 \\
100 \cdot 00\end{array}$ & $\begin{array}{l}493 \\
678 \\
169 \\
847 \\
256 \\
127 \\
636\end{array}$ & $\begin{array}{r}17 \cdot 35 \\
17 \cdot 65 \\
15 \cdot 03 \\
17 \cdot 01 \\
20 \cdot 46 \\
9 \cdot 85 \\
4 \cdot 74\end{array}$ \\
\hline essive & $9 \cdot 28$ & $5 \cdot 85$ & 4 & $\cdot 23$ & $\cdot 42$ & 20.00 & 13.83 & 94 & 00 & 823 & $8 \cdot 54$ \\
\hline $\begin{array}{l}\text { psychosis } \\
\text { Hysteria } \\
\text { *Schizophrenia }\end{array}$ & $\begin{array}{l}5 \cdot 41 \\
8 \cdot 55 \\
8 \cdot 34\end{array}$ & $\begin{array}{l}5 \cdot 25 \\
5 \cdot 89 \\
6 \cdot 42\end{array}$ & $\begin{array}{r}7 \cdot 84 \\
9 \cdot 67 \\
11 \cdot 33\end{array}$ & $\begin{array}{r}13 \cdot 07 \\
9 \cdot 51 \\
15 \cdot 34\end{array}$ & $\begin{array}{l}13 \cdot 24 \\
16 \cdot 85 \\
14 \cdot 86\end{array}$ & $\begin{array}{l}15 \cdot 77 \\
18 \cdot 16 \\
18 \cdot 13\end{array}$ & $\begin{array}{r}18 \cdot 60 \\
16 \cdot 13 \\
9 \cdot 30\end{array}$ & $\begin{array}{l}20 \cdot 83 \\
15 \cdot 24 \\
16 \cdot 27\end{array}$ & & $\begin{array}{l}345 \\
426 \\
179\end{array}$ & $\begin{array}{l}6 \cdot 73 \\
8 \cdot 41 \\
8 \cdot 72\end{array}$ \\
\hline
\end{tabular}

* Sample includes 1944 cases.

TABLE V

Relative Discharge Rates in 6-year Age Groups during 1943 with RESPECT TO MALE OTHER RANKS

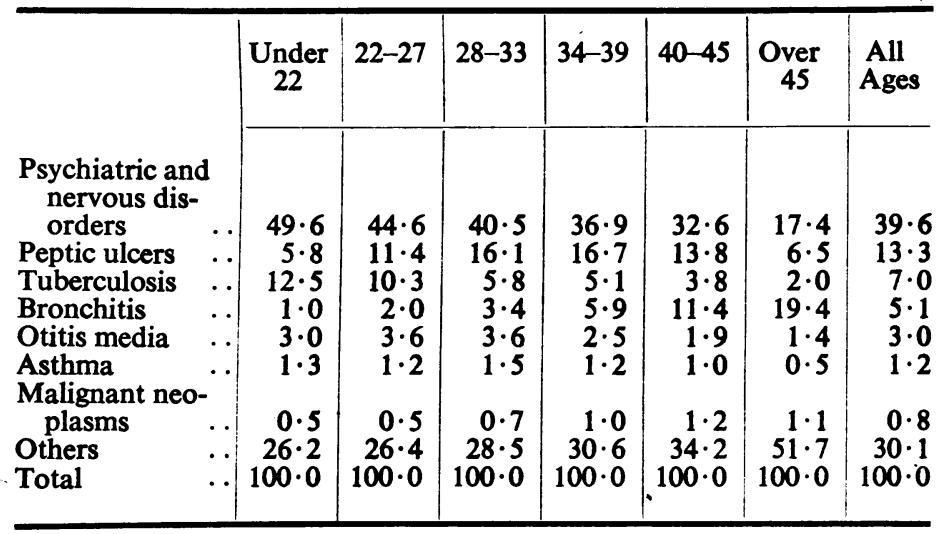

Table V summarizes available data with respect to which diseases are more or less important as a source of permanent wastage in different age groups of the Army population. In the age group under 28, psychiatric and nervous disorders account for nearly half of all discharges. If we add peptic ulcers, tuberculosis,

I.L.O. Occupation and Health, Geneva, 1934. 
bronchitis, otitis media, and asthma, we have accounted for nearly $75 \%$ of all discharges within this age group; and of those included tuberculosis is by far the most noteworthy item in the age group under 22 . In the $40-45$ age group psychiatric and nervous disorders on the one hand, and diseases other than those mentioned above on the other, each account for almost exactly one-third of all discharges, and peptic ulcers together with bronchitis for a quarter. The age-group over 45 tells quite a different story. Bronchitis alone accounts for about one-fifth of all discharges. It is now a more important source of wastage than psychiatric and.

TABLE VI

Annual Age Standardizing Factors for Discharge Rates; Male Other Ranks

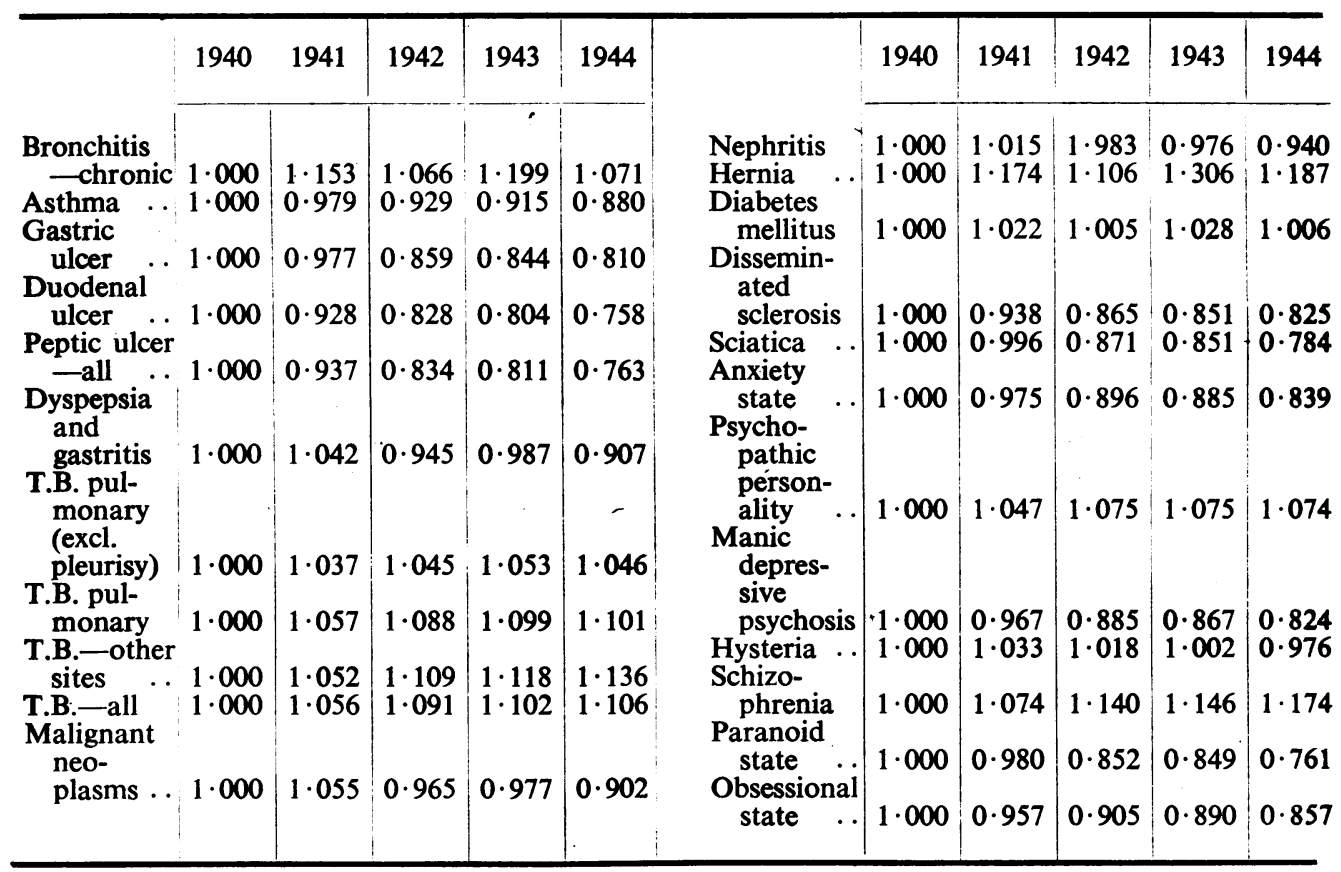

nervous disorders ; and diseases other than those specifically mentioned in this context now account for more than half the total discharges.

Broadly speaking we may thus summarize the experience of the war years:

(i) if the youngest age groups of an Army population predominate, the two chief sources of wastage are psychiatric disorders and tuberculosis;

(ii) if the middle age groups predominate, the two chief sources of wastage are psychiatric disorders and peptic ulcers;

(iii) if the oldest age group were to predominate, the two chief sources of wastage would be bronchitis and psychiatric disorders.

Since the age composition of the Army changed considerably between 1939 
and 1945, conclusions presented in Tables III to $\mathrm{V}$ have a profound bearing on the interpretation of the trend of crude discharge rates during the war. Two main features of this change were: (i) a steady fall of the proportion of very young men; (ii) a concomitant decrease in the oldest (over 45) age group. The effect of this may be such as would wholly invalidate impressions gained from the trend of discharge rates with respect to individual diseases, if the risk of contracting them or the gravity of their manifestations rises or falls steadily as age advances. If the incidence of a disease increases very sharply only at the tail end of life the distortion is less conspicuous. Since the A.T.S. was at all times a younger population than male Army personnel, comparisons between crude discharge rates for women and men may give rise to even more erroneous conclusions than comparisons of discharge rates for the same class of personnel at different stages in

TABLE VII

Annual Age Standardizing Factors for Discharge Rates; A.T.S. Auxiliaries

\begin{tabular}{|c|c|c|c|c|c|c|c|c|c|c|}
\hline & & & \multicolumn{4}{|c|}{$\begin{array}{l}\text { (a) with respect to Military } \\
\text { Strength, } 1940\end{array}$} & \multicolumn{4}{|c|}{$\begin{array}{l}\text { (b). with respect to A.T.S. } \\
\text { Strength, } 1941\end{array}$} \\
\hline & & & 1941 & 1942 & 1943 & 1944. & 1941 & 1942 & 1943 & 1944 \\
\hline 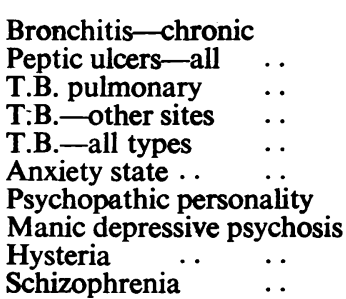 & $\begin{array}{c}\ldots \\
\ldots \\
\ldots \\
\ldots \\
\ldots \\
\ldots \\
\ldots \\
\ldots\end{array}$ & & $\begin{array}{l}1.067 \\
1.048 \\
0.965 \\
0.964 \\
0.964 \\
1.144 \\
0.996 \\
1.050 \\
1.008 \\
1.023\end{array}$ & $\begin{array}{l}1 \cdot 732 \\
1 \cdot 329 \\
0 \cdot 899 \\
0 \cdot 912 \\
0 \cdot 902 \\
1 \cdot 571 \\
1 \cdot 080 \\
1 \cdot 250 \\
1 \cdot 105 \\
1 \cdot 120\end{array}$ & $\begin{array}{l}2.018 \\
1.442 \\
0.899 \\
0.925 \\
0.905 \\
1.677 \\
1 \cdot 150 \\
1 \cdot 315 \\
1 \cdot 169 \\
1 \cdot 176\end{array}$ & $\begin{array}{l}1.970 \\
1.435 \\
0.915 \\
0.948 \\
0.922 \\
1.615 \\
1.181 \\
1.297 \\
1.190 \\
1 \cdot 180\end{array}$ & $\begin{array}{l}1.000 \\
1.000 \\
1.000 \\
1.000 \\
1.000 \\
1.000 \\
1.000 \\
1.000 \\
1.000 \\
1.000\end{array}$ & $\begin{array}{l}1 \cdot 624 \\
1.268 \\
0.932 \\
0.946 \\
0.935 \\
1.373 \\
1.085 \\
1 \cdot 191 \\
1.097 \\
1.095\end{array}$ & $\begin{array}{l}1 \cdot 892 \\
1 \cdot 375 \\
0 \cdot 932 \\
0 \cdot 960 \\
0 \cdot 938 \\
1 \cdot 465 \\
1 \cdot 155 \\
1 \cdot 253 \\
1 \cdot 161 \\
1 \cdot 150\end{array}$ & $\begin{array}{l}1 \cdot 847 \\
1 \cdot 369 \\
0.949 \\
0.983 \\
0.956 \\
1 \cdot 411 \\
1 \cdot 186 \\
1 \cdot 235 \\
1 \cdot 181 \\
1 \cdot 154\end{array}$ \\
\hline
\end{tabular}

the war. Tables VI and VII illustrate the magnitude of this source of erroneous comparison by citing appropriate standardizing factors. A single example will suffice to illustrate how gross errors may arise from comparison of crude rates on account of differences of age composition. The 1944 S.F. of A.T.S. auxiliaries (with respect to 1940 military strength) for peptic ulcers is 1.435 . For the 1944 male population the corresponding S.F. is $0 \cdot 763$. To make the 1944 discharge rate of peptic ulcer among women comparable with that of males in the same year we have, therefore, to increase it in the ratio $1.435: 0.763$, i.e. we have to multiply it by $1 \cdot 435 \div 0 \cdot 763=1 \cdot 9$. Thus age alone can suffice to account for a difference of nearly $1: 2$.

\section{Relation of Age to Hospital Admissions in the United Kingdom}

An obstacle to a wholly satisfactory analysis of hospital record cards as raw materials for the present objective has been the difficulty of obtaining a precise estimate of the populations at risk. Before re-organization of Army medical 
statistics in the fall of 1944, need for age-strength distributions of the Army in each theatre was not recognized. Returns embodying the basic data were not in fact available until 1945. For the purpose of what follows, it has therefore been necessary to make an approximate estimate of the age structure of the United Kingdom population at risk during the years (1943 and 1944) for which the largest samples of data are available. In 1943 about $60 \%$ of the Army were still at home. As a first approximation (I) we might therefore take the 1943 age composition of the Army in the United Kingdom to be that of the Army as a whole in the same year. As a second approximation (II), we may estimate what the United Kingdom distribution would have been, if the only relevant selective process involved in dispatch of troops to overseas commands had been the exclusion of the age group under 19. Clearly, the first approximation underestimates the relative strength of the youngest Army age group in the United Kingdom and would, therefore, lead one to compute unduly high values of the relative incidence of diseases therein; but the alternative supposition takes no cognisance of the exclusion from overseas service of category " $C$ " personnel among whom we have sufficient reasons to infer a preponderance of older age groups. An assessment based on this supposition therefore underestimates the size of the latter in the residual (United Kingdom) population, and would hence lead to unduly high relative specific rates in the older part of the age-range.

In fact, the computation of age incidence distributions for the diseases cited below on the basis of either approximation leads to results which do not greatly differ; and it is happily possible to arrive at an estimate (III) which is more plausible than either. With due consideration to the ratio of total home and overseas strengths, comparison between the separately known age-strength (1945) distributions of the Army in the United Kingdom and the Army as a whole, permits us to infer the age distribution of the segment of the Army population then excluded from overseas service above the age of 19 . Presumably, this corresponds closely to the age distribution of personnel rejected on account of low medical category. Above the age of 22 this distribution is approximately parabolic. If we reject the age group under 19 as before, a quadratic formula convenient for computation leads to a fit good enough for the purpose in hand. The actual age distribution of the Army in the United Kingdom, March 1945, and the distribution computed by the formula are as follows:

\begin{tabular}{|c|c|c|c|c|c|c|c|c|c|c|c|}
\hline U.K. 1945 & $<22$ & $22-24$ & $25-27$ & $28-30$ & $31-33$ & 34-36 & $37-39$ & $40-42$ & $43-45$ & $>45$ & Total \\
\hline $\begin{array}{l}\text { Calculated } \\
\text { Actual }\end{array}$ & $\begin{array}{l}21 \cdot 2 \\
20 \cdot 9\end{array}$ & $\begin{array}{r}9 \cdot 9 \\
10 \cdot 2\end{array}$ & $\begin{array}{l}12 \cdot 2 \\
12 \cdot 6\end{array}$ & $\begin{array}{l}12 \cdot 7 \\
13 \cdot 4\end{array}$ & $\begin{array}{l}12 \cdot 5 \\
12 \cdot 6\end{array}$ & $\begin{array}{l}11 \cdot 1 \\
10 \cdot 7\end{array}$ & $\begin{array}{l}9 \cdot 2 \\
8 \cdot 6\end{array}$ & $\begin{array}{l}6 \cdot 2 \\
5 \cdot 9\end{array}$ & $\begin{array}{l}3 \cdot 3 \\
3 \cdot 4\end{array}$ & $\begin{array}{l}1 \cdot 7 \\
1 \cdot 7\end{array}$ & $\begin{array}{l}100 \\
100\end{array}$ \\
\hline
\end{tabular}

Our third estimate (III) is based on the assumption that the age distribution of personnel rejected for overseas service as too young or of too low medical category 
was in June 1943 approximately the same as in March 1945, in accordance with the formula used for computing the upper distribution of the preceding table. As shown below, the three estimates do not diverge grossly; and general conclusions stated in the text below are in fact consistent with distributions calculated on any of the three assumptions I-III specified.

\begin{tabular}{|c|c|c|c|c|c|c|c|c|c|c|c|}
\hline $\begin{array}{l}\text { Estimated } \\
\text { U.K. } 1943\end{array}$ & $<22$ & $22-24$ & $25-27$ & $28-30$ & 31-33 & $34-36$ & $37-39$ & $40-42$ & $43-45$ & $>45$ & Total \\
\hline$\underset{\text { III }}{\text { II }}$ & $\begin{array}{l}15 \cdot 1 \\
16 \cdot 8 \\
17 \cdot 2\end{array}$ & $\begin{array}{l}18 \cdot 7 \\
18 \cdot 3 \\
16 \cdot 5\end{array}$ & $\begin{array}{l}16 \cdot 9 \\
16 \cdot 5 \\
15 \cdot 3\end{array}$ & $\begin{array}{l}15 \cdot 6 \\
15 \cdot 3 \\
14 \cdot 6\end{array}$ & $\begin{array}{l}13.0 \\
12.7 \\
12.9\end{array}$ & $\begin{array}{l}9 \cdot 2 \\
9 \cdot 1 \\
9 \cdot 7\end{array}$ & $\begin{array}{l}6 \cdot 1 \\
6 \cdot 0 \\
6 \cdot 8\end{array}$ & $\begin{array}{l}3 \cdot 6 \\
3 \cdot 5 \\
4 \cdot 4\end{array}$ & $\begin{array}{l}0.9 \\
0.9 \\
1.2\end{array}$ & $\begin{array}{l}0.9 \\
0.9 \\
1.3\end{array}$ & $\begin{array}{l}100 \\
100 \\
100\end{array}$ \\
\hline
\end{tabular}

Table VIII is, in fact, based upon our third assumption which is undoubtedly preferable, but it will bring into focus how small is the order of error involved if we cite six distributions as calculated on assumptions I and III separately. The examples chosen illustrate descending, relatively flat, and ascending contours.

\begin{tabular}{|c|c|c|c|c|c|c|c|c|c|c|c|c|}
\hline & & $<22$ & $22-24$ & $25-27$ & $28-30$ & $31-33$ & $34-36$ & $37-39$ & $40-42$ & $43-45$ & $>45$ & Total \\
\hline Rubella & III & $\begin{array}{l}53 \cdot 41 \\
50 \cdot 50\end{array}$ & $\begin{array}{l}3 \cdot 88 \\
4 \cdot 76\end{array}$ & $\begin{array}{l}6 \cdot 96 \\
8 \cdot 23\end{array}$ & $\begin{array}{r}8 \cdot 84 \\
10 \cdot 25\end{array}$ & $\begin{array}{l}6 \cdot 69 \\
7 \cdot 22\end{array}$ & $\begin{array}{l}7 \cdot 10 \\
7 \cdot 36\end{array}$ & $\begin{array}{l}5 \cdot 62 \\
5 \cdot 34\end{array}$ & $\begin{array}{l}3 \cdot 21 \\
2 \cdot 89\end{array}$ & $\begin{array}{l}2 \cdot 81 \\
2 \cdot 31\end{array}$ & $\begin{array}{l}1 \cdot 47 \\
1 \cdot 15\end{array}$ & $\begin{array}{l}100 \\
100\end{array}$ \\
\hline $\begin{array}{l}\text { Glandular } \\
\text { fever }\end{array}$ & III & $\begin{array}{l}35 \cdot 27 \\
32 \cdot 45\end{array}$ & \begin{tabular}{|l|}
$11 \cdot 49$ \\
$13 \cdot 59$
\end{tabular} & \begin{tabular}{|l|}
$16 \cdot 64$ \\
$19 \cdot 28$ \\
\end{tabular} & $\begin{array}{l}8 \cdot 72 \\
9 \cdot 71\end{array}$ & $\begin{array}{l}4 \cdot 49 \\
4 \cdot 72\end{array}$ & $\begin{array}{l}5 \cdot 28 \\
5 \cdot 27\end{array}$ & $\begin{array}{l}4 \cdot 76 \\
4 \cdot 44\end{array}$ & $\begin{array}{l}2 \cdot 64 \\
2 \cdot 36\end{array}$ & $\begin{array}{l}5 \cdot 15 \\
4 \cdot 16\end{array}$ & $\begin{array}{l}5 \cdot 55 \\
4 \cdot 02\end{array}$ & $\begin{array}{l}100 \\
100\end{array}$ \\
\hline $\begin{array}{l}\text { T.B.- } \\
\text { pulmonary }\end{array}$ & III & $\begin{array}{l}8 \cdot 46 \\
8 \cdot 50\end{array}$ & $\begin{array}{l}6 \cdot 12 \\
7 \cdot 92\end{array}$ & $\begin{array}{l}5 \cdot 90 \\
7 \cdot 42\end{array}$ & $\begin{array}{l}5.54 \\
6.75\end{array}$ & $\begin{array}{l}5 \cdot 61 \\
6 \cdot 50\end{array}$ & $\begin{array}{l}8 \cdot 89 \\
9 \cdot 67\end{array}$ & \begin{tabular}{|l|}
$10 \cdot 85$ \\
11.08
\end{tabular} & $\begin{array}{l}12 \cdot 82 \\
12 \cdot 17\end{array}$ & & $\begin{array}{l}17.48 \\
14.08\end{array}$ & $\begin{array}{l}100 \\
100\end{array}$ \\
\hline $\begin{array}{l}\text { Lobar } \\
\text { pneumonia }\end{array}$ & III & $\begin{array}{l}13 \cdot 42 \\
13 \cdot 80\end{array}$ & $\begin{array}{l}4 \cdot 92 \\
6 \cdot 52\end{array}$ & $\begin{array}{l}4 \cdot 49 \\
5 \cdot 77\end{array}$ & $\begin{array}{l}5 \cdot 78 \\
7 \cdot 19\end{array}$ & $\begin{array}{l}5 \cdot 56 \\
6 \cdot 61\end{array}$ & $\begin{array}{l}7 \cdot 56 \\
8 \cdot 44\end{array}$ & & $\begin{array}{l}7 \cdot 63 \\
7 \cdot 36\end{array}$ & & $\begin{array}{l}29.98 \\
24.58\end{array}$ & $\begin{array}{l}100 \\
100\end{array}$ \\
\hline & III & $\begin{array}{l}1 \cdot 21 \\
1 \cdot 27\end{array}$ & $\begin{array}{l}1 \cdot 91 \\
2 \cdot 66\end{array}$ & $\begin{array}{l}2 \cdot 34 \\
3 \cdot 12\end{array}$ & $\begin{array}{l}3 \cdot 49 \\
4 \cdot 51\end{array}$ & $\begin{array}{l}6 \cdot 46 \\
7 \cdot 87\end{array}$ & $\begin{array}{r}9 \cdot 14 \\
10 \cdot 58\end{array}$ & $\begin{array}{l}10 \cdot 29 \\
11 \cdot 10\end{array}$ & $\begin{array}{l}14 \cdot 64 \\
14 \cdot 63\end{array}$ & & $\begin{array}{l}29 \cdot 28 \\
24 \cdot 81\end{array}$ & $\begin{array}{l}100 \\
100\end{array}$ \\
\hline $\begin{array}{l}\text { Chronic } \\
\text { bronchitis }\end{array}$ & III & $\begin{array}{l}1.80 \\
1.95\end{array}$ & $\begin{array}{l}1 \cdot 66 \\
2 \cdot 31\end{array}$ & $\begin{array}{l}2 \cdot 0 \\
2 \cdot 9\end{array}$ & $\begin{array}{l}2.95 \\
3.90\end{array}$ & $\begin{array}{l}3 \cdot 91 \\
4 \cdot 87\end{array}$ & $\begin{array}{l}6 \cdot 48 \\
7 \cdot 64\end{array}$ & $\begin{array}{l}10 \cdot 56 \\
11 \cdot 59\end{array}$ & $\begin{array}{l}13 \cdot 92 \\
14 \cdot 21\end{array}$ & $\begin{array}{l}24 \cdot 81 \\
23 \cdot 18\end{array}$ & $\begin{array}{l}31 \cdot 88 \\
27 \cdot 59\end{array}$ & $\begin{array}{l}100 \\
100\end{array}$ \\
\hline
\end{tabular}

It is possible to get a check on the above procedure for estimating the age structure of the male population by comparing age incidence distributions of discharges with those of hospital admissions so computed. With this end in view we have to rely on diseases which are (a) sufficiently common to yield large examples; (b) so severe as to lead to early discharge, when recognized.

So defined, the best "marker" diseases are peptic ulcers and pulmonary tuberculosis, as shown in Table IX, setting forth age-incidence distributions of male hospital admissions based on estimate III, side by side with age distributions of medical discharges. Specification of the appropriate female (A.T.S.) population at risk in each group offers no special difficulties, because the proportion of women serving overseas in 1943-4 was trivial. 
The most striking feature of Table VIII is the contrast between the age-incidence distributions of acute infections on the one hand and of non-communicable diseases or chronic infections on the other. With few exceptions discussed below, the general rule is that the incidence of acute infections falls off with increasing age and most steeply in the youngest age groups, as illustrated by the accompanying histogram of diphtheria (Fig. 5). To the extent that an attack confers more or less immunity, this is intelligible. The residual proportion not immunized by previous attack must then fall off in successive years of life, and the effective population at risk therefore becomes successively smaller than the total strength in a given age group. If this is a sufficient explanation of the phenomenon, two
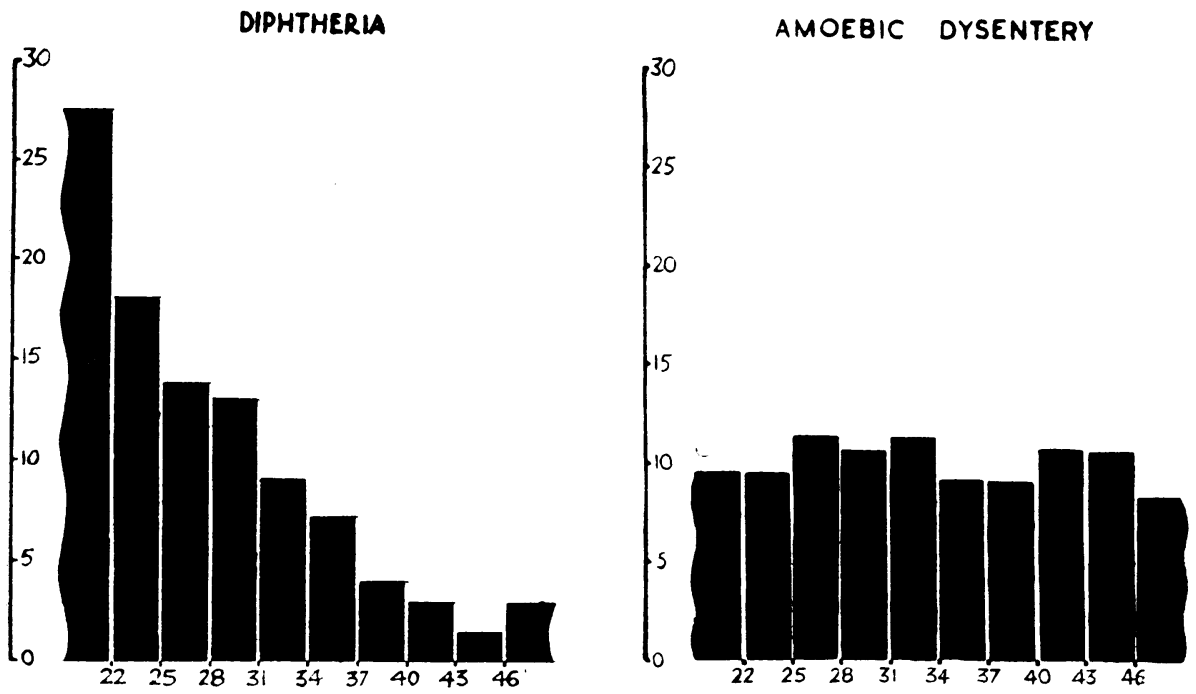

FIG. 5.-Relative age-incidence distributions based on hospital admissions of 779 male cases of diphtheria in U.K. (left) and 1,501 male cases of amoebic dysentery (right) in Middle East.

conclusions follow. Ceteris paribus, the decline of incidence with advancing age should be: $(a)$ less steep if the disease is more rare; $(b)$ more steep if a single attack itself suffices to confer complete immunity, as is supposedly true of most virus diseases. It is therefore suggestive that: (i) rubella, measles, mumps and chickenpox show a steeper decline than other diseases listed; (ii) of these virus diseases, rubella-which is the most common-also shows the steepest fall; (iii) in contrast with the declining incidence of scarlet fever, the incidence of erysipelas-likewise a haemolytic streptococcal infection but one which confers little or no immunity-steadily increases as age advances. That gonorrhoea and syphilis also fall out of step with communicable diseases such as diphtheria, measles, or infective hepatitis, is what we should expect, since we know that an attack of gonorrhoea confers little or no immunity and that syphilitics treated early with arsenicals, can get a subsequent infection. 
Since a single clear-cut difference, especially one putatively attributable to such a fundamental phenomenon as immunity, suffices to override any number of striking similarities when the identity of two conditions is under dispute, the age distributions of post-arsphenamine jaundice and infective hepatitis (Fig. 6) are particularly instructive in connexion with recent controversy arising from the discovery that the former is due to an icterogenic agent spread by imperfectly sterilized syringes. The distribution of infective hepatitis, here shown, confirms the general clinical impression that it is a disease to which younger age groups are specially prone. To that extent its behaviour is typical of communicable diseases. The age incidence
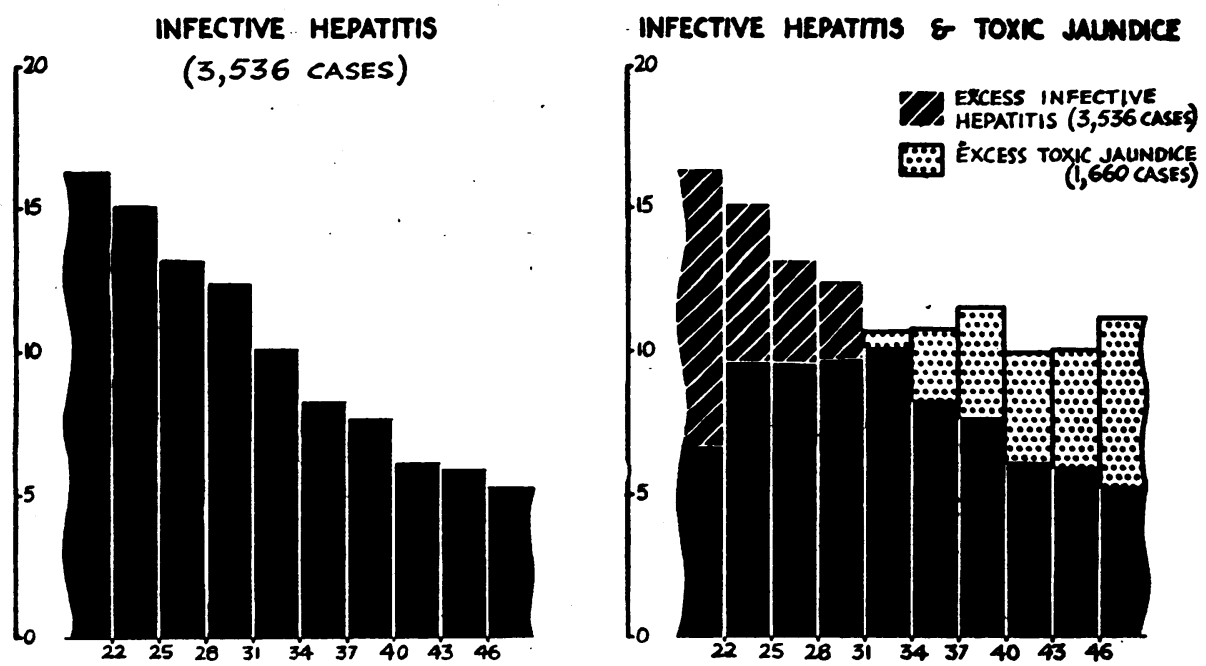

Frg. 6.-Relative age-incidence distributions of 3,536 male hospital admissions of infective hepatitis on the left; on the right, superimposed histograms of the foregoing and of postarsphenamine jaundice among the syphilitic population (1,660 male cases). Excess of postarsphenamine jaundice dotted, excess of infective hepatitis shaded.

distribution of post-arsphenamine jaundice (related to the correct population at risk, i.e. to syphilitics) is altogether different. This fact, as also the different seasonal distributions of the two diseases, is strong evidence against a recently prevalent belief that the same virus is responsible for both these conditions.

Exceptions to the general rule stated above, other than those mentioned, are scabies, pulmonary tuberculosis, and pneumonia. The first-named scarcely calls for comment, since its inclusion in the table as a communicable condition is merely a matter of convenience. Since death (or discharge) removes from the apparent population at risk individuals who might otherwise be immune to subsequent attack, the considerations advanced above do not apply to a wholly and rapidly fatal disease, and apply with less force to any disease which has a high fatality-as have tuberculosis and pneumonia. Even if this were not so, there are other reasons for anticipating the possibility that they would fall out of step with other infections. Since pulmonary tuberculosis is a protracted disease which may long remain latent, 
TABLE VIII

Relative Age-Incidence Distribution of Admissions to Hospital in the U.K.; Male Other Ranks

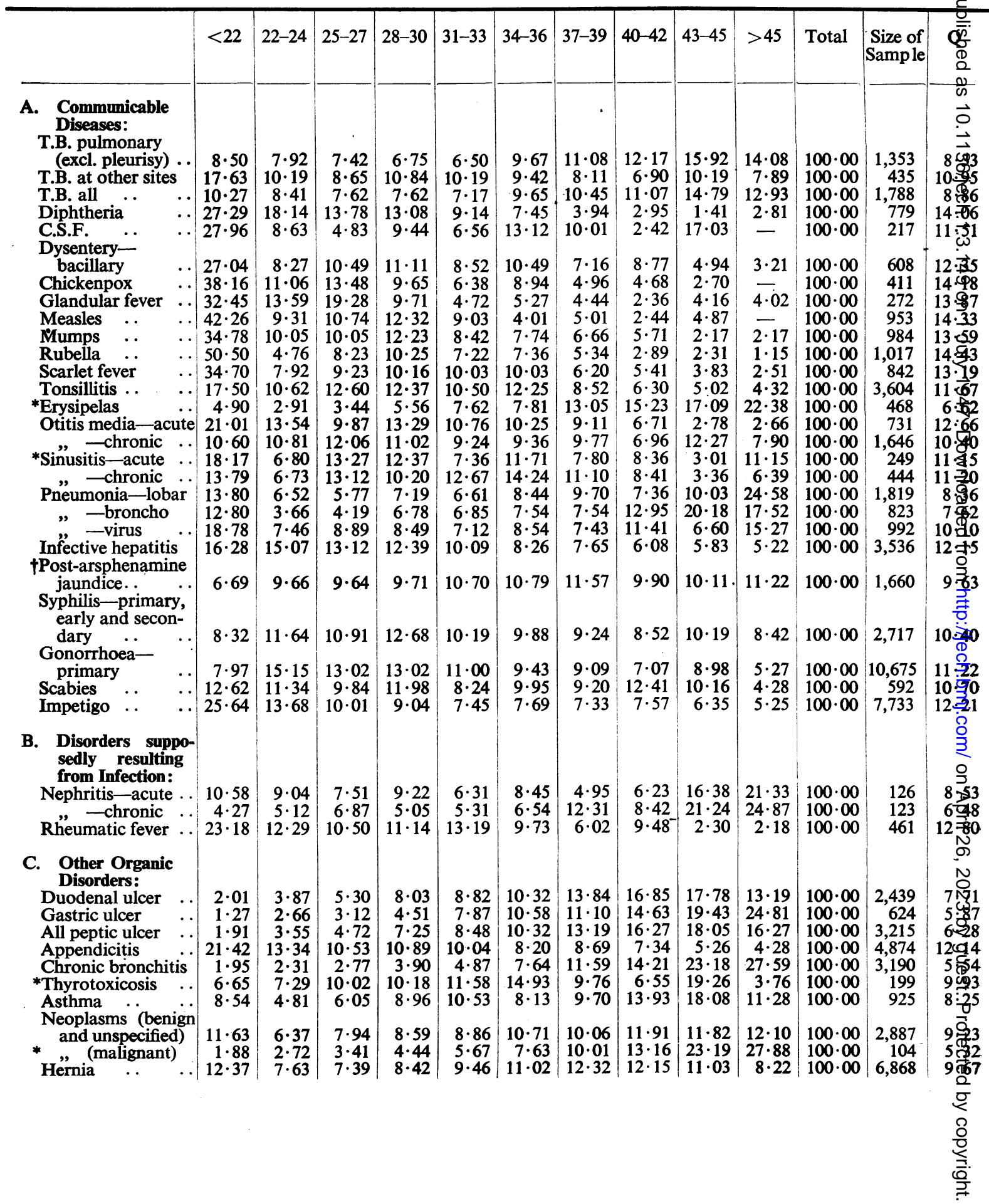




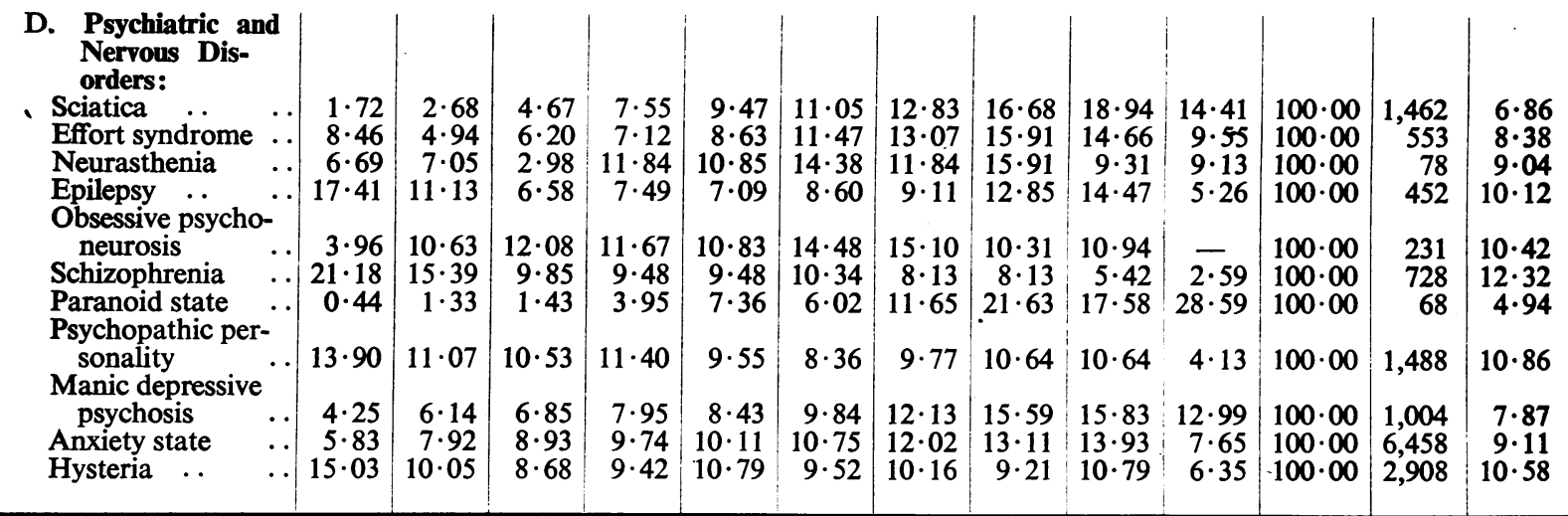

* Sample includes 1944 cases.

$\dagger$ Strength used was the age-distribution of syphilis cases.

becoming manifest at a late stage under conditions of stress, we cannot assume that an age distribution based on the time at which diagnosis takes place tallies closely with an age distribution based on the time at which infection actually occurs. Lobar pneumonia, which also has a relatively high fatality rate, is attributable to a variety of distinguishable types and of strains within one and the same type; and secondary pneumonias constitute an even more heterogeneous assemblage. It is therefore arguable that exceptions to the rule stated are more apparent than real; and that they are, indeed, the class of exceptions that prove the rule.

Of diseases which oppress the younger age groups most, two on our list, namely appendicitis and schizophrenia, do not come within the class of communicable conditions. A possible explanation of the age distribution of the first is in line with the one offered above. Appendicectomy is now a relatively common practice; and like immunity implies the build-up of a residual population incapable of subsequent attack. The characteristic distribution of schizophrenia is intelligible if we regard it as a congenital disposition of which the diagnosis depends in large measure on failure of the subject to fulfil new social demands imposed by adult life.

Of two diseases supposedly due to infection, rheumatic fever conforms to the general rule stated above. Evidence concerning the origin of acute nephritis is more conflicting. Its singularity as a clinical entity is more dubious, and its age distribution is not typical of communicable diseases in general. Remaining organic disorders listed include: peptic ulcers, malignant neoplasms, chronic bronchitis, asthma, hernia and benign neoplasms. The incidence of gastric ulcer and chronic bronchitis increases steeply with advancing age to the limit of the range. That of duodenal ulcer initially increases more steeply than that of gastric ulcer, but attains a peak about 44 years of age. Fig. 4 shows the use of the peptic ulcers as marker diseases in the sense already defined. The close correspondence between distributions based on medical discharges and hospital records provides a satisfactory check on the demographic estimates employed in the treatment of data derived from the latter. 
TABLE IX

Comparison of Relative Age-Incidence Distributions of Admissions to Hospital in U.K. afid of Discharges from the ARMY on Medical Grounds; Male Other RaNKS

\begin{tabular}{|c|c|c|c|c|c|c|c|c|c|c|c|c|}
\hline & $<22$ & $22-24$ & $25-27$ & $28-30$ & $31-33$ & $34-36$ & $37-39$ & $40-42$ & $43-45$ & $>45$ & Total & $\begin{array}{l}\text { Size 躴 } \\
\text { Sampite }\end{array}$ \\
\hline $\begin{array}{r}\text { Diseases : } \\
\text { Addmissions } \\
\text { Discharges }\end{array}$ & $\begin{array}{r}11 \cdot 20 \\
4 \cdot 30\end{array}$ & $\begin{array}{l}8 \cdot 89 \\
3 \cdot 42\end{array}$ & $\begin{array}{l}8 \cdot 42 \\
3 \cdot 77\end{array}$ & $\begin{array}{l}9 \cdot 62 \\
4 \cdot 36\end{array}$ & $\begin{array}{l}9 \cdot 11 \\
5 \cdot 43\end{array}$ & $\begin{array}{l}9 \cdot 65 \\
6 \cdot 73\end{array}$ & $\begin{array}{r}10 \cdot 22 \\
8 \cdot 64\end{array}$ & $\begin{array}{l}10 \cdot 02 \\
12 \cdot 81\end{array}$ & $\begin{array}{l}12.42 \\
17.95\end{array}$ & $\begin{array}{l}10 \cdot 47 \\
32 \cdot 39\end{array}$ & $\begin{array}{l}100 \cdot 00 \\
100 \cdot 00\end{array}$ & \\
\hline $\begin{array}{l}\text { A. Communicable } \\
\text { Diseases: } \\
\text { T.B. pulmonary }\end{array}$ & & & & & & & & & & & & \\
\hline $\begin{array}{r}\text { Admissions } \\
\text { *Discharges } \\
\text { B at other sites }\end{array}$ & $\begin{array}{l}8 \cdot 50 \\
8 \cdot 81\end{array}$ & $\begin{array}{l}7 \cdot 92 \\
8 \cdot 02\end{array}$ & $\begin{array}{l}7 \cdot 42 \\
7 \cdot 72\end{array}$ & $\begin{array}{l}6 \cdot 75 \\
6 \cdot 80\end{array}$ & $\begin{array}{l}6 \cdot 50 \\
6 \cdot 70\end{array}$ & $\begin{array}{l}9 \cdot 67 \\
8 \cdot 26\end{array}$ & $\begin{array}{r}11 \cdot 08 \\
9.56\end{array}$ & $\begin{array}{l}12 \cdot 17 \\
11 \cdot 08\end{array}$ & $\begin{array}{l}15 \cdot 92 \\
16 \cdot 02\end{array}$ & \begin{tabular}{|l|}
$14 \cdot 08$ \\
17.03
\end{tabular} & $\begin{array}{l}100 \cdot 00 \\
100 \cdot 00\end{array}$ & $\begin{array}{l}1,3 \\
4,7\end{array}$ \\
\hline $\begin{array}{r}\text { Admissions } \\
\text { *Discharges }\end{array}$ & $\begin{array}{l}17 \cdot 63 \\
16 \cdot 18\end{array}$ & $\begin{array}{l}10 \cdot 19 \\
10 \cdot 27\end{array}$ & $\begin{array}{r}8 \cdot 65 \\
10 \cdot 40\end{array}$ & $\begin{array}{l}10 \cdot 84 \\
10 \cdot 09\end{array}$ & $\begin{array}{r}10 \cdot 19 \\
8 \cdot 12\end{array}$ & $\begin{array}{l}9 \cdot 42 \\
8 \cdot 52\end{array}$ & $\begin{array}{l}8 \cdot 11 \\
8 \cdot 72\end{array}$ & $\begin{array}{l}6 \cdot 90 \\
7 \cdot 57\end{array}$ & $\begin{array}{r}10 \cdot 19 \\
9 \cdot 58\end{array}$ & $\begin{array}{r}7 \cdot 89 \\
10 \cdot 55\end{array}$ & $\begin{array}{l}100 \cdot 00 \\
100 \cdot 00\end{array}$ & 9 \\
\hline $\begin{array}{l}\text { C. Other Organic } \\
\text { Disorders: } \\
\text { Duodenal ulcer }\end{array}$ & & & & & & & & & & & & \\
\hline $\begin{array}{l}\text { Admissions } \\
\text { Discharges } \\
\text { Gastric ulcer }\end{array}$ & $\begin{array}{l}2 \cdot 01 \\
2 \cdot 21\end{array}$ & $\begin{array}{l}3 \cdot 87 \\
3 \cdot 33\end{array}$ & $\begin{array}{l}5 \cdot 30 \\
4 \cdot 59\end{array}$ & $\begin{array}{l}8 \cdot 03 \\
7 \cdot 35\end{array}$ & $\begin{array}{l}8 \cdot 82 \\
8 \cdot 78\end{array}$ & $\begin{array}{l}10 \cdot 32 \\
10 \cdot 96\end{array}$ & $\begin{array}{l}13 \cdot 84 \\
13 \cdot 21\end{array}$ & $\begin{array}{l}16 \cdot 85 \\
16 \cdot 76\end{array}$ & $\begin{array}{l}17 \cdot 78 \\
17 \cdot 49\end{array}$ & $\begin{array}{l}13 \cdot 19 \\
15 \cdot 30\end{array}$ & $\begin{array}{l}100 \cdot 00 \\
100 \cdot 00\end{array}$ & 2,4390 \\
\hline $\begin{array}{r}\text { Gastric ulcer } \\
\text { Admissions } \\
\text { Discharges } \\
\text { All peptic ulcers }\end{array}$ & $\begin{array}{l}1 \cdot 27 \\
1 \cdot 51\end{array}$ & $\begin{array}{l}2 \cdot 66 \\
1 \cdot 98\end{array}$ & $\begin{array}{l}3 \cdot 12 \\
2 \cdot 71\end{array}$ & $\begin{array}{l}4 \cdot 51 \\
4 \cdot 34\end{array}$ & $\begin{array}{l}7 \cdot 87 \\
5 \cdot 90\end{array}$ & $\left|\begin{array}{r}10 \cdot 58 \\
9 \cdot 75\end{array}\right|$ & $\begin{array}{l}11 \cdot 10 \\
12 \cdot 61\end{array}$ & $\begin{array}{l}14 \cdot 63 \\
16 \cdot 71\end{array}$ & $\begin{array}{l}19 \cdot 43 \\
19 \cdot 38\end{array}$ & \begin{tabular}{|}
$24 \cdot 81$ \\
$25 \cdot 12$
\end{tabular} \mid & & 6 \\
\hline $\begin{array}{c}\text { Admissions } \\
\text { Discharges } \\
\text { Chronic bronchitis }\end{array}$ & $\begin{array}{l}1.91 \\
2.06\end{array}$ & $\begin{array}{l}3 \cdot 55 \\
3 \cdot 03\end{array}$ & $\begin{array}{l}4 \cdot 72 \\
4 \cdot 15\end{array}$ & $\begin{array}{l}7 \cdot 25 \\
6 \cdot 63\end{array}$ & $\begin{array}{l}8 \cdot 48 \\
8 \cdot 13\end{array}$ & $\begin{array}{l}10 \cdot 32 \\
10 \cdot 62\end{array}$ & $\begin{array}{l}13 \cdot 19 \\
13 \cdot 08\end{array}$ & $\begin{array}{l}16 \cdot 27 \\
16 \cdot 92\end{array}$ & $\begin{array}{l}18.05 \\
17.98\end{array}$ & $\begin{array}{l}16 \cdot 27 \\
17 \cdot 41\end{array}$ & $\begin{array}{l}100 \cdot 00 \\
100 \cdot 00\end{array}$ & $\begin{array}{l}3,215 \stackrel{6}{\circ} \\
5,843\end{array}$ \\
\hline $\begin{array}{r}\text { Admissions } \\
\text { Discharges }\end{array}$ & $\begin{array}{l}1 \cdot 95 \\
0 \cdot 34\end{array}$ & $\begin{array}{l}2 \cdot 31 \\
0 \cdot 49\end{array}$ & $\begin{array}{l}2 \cdot 77 \\
0 \cdot 75\end{array}$ & $\begin{array}{l}3 \cdot 90 \\
1 \cdot 11\end{array}$ & $\begin{array}{l}4 \cdot 87 \\
2 \cdot 07\end{array}$ & $\begin{array}{l}7 \cdot 64 \\
2 \cdot 98\end{array}$ & $\begin{array}{r}11 \cdot 59 \\
5 \cdot 83\end{array}$ & $\begin{array}{l}14 \cdot 21 \\
12 \cdot 01\end{array}$ & $\begin{array}{l}23 \cdot 18 \\
22 \cdot 45\end{array}$ & \begin{tabular}{|}
$27 \cdot 59$ \\
$51 \cdot 97$
\end{tabular} & \begin{tabular}{|l|}
$100 \cdot 00$ \\
$100 \cdot 00$
\end{tabular} & $\begin{array}{l}3,190 \\
2,181=\end{array}$ \\
\hline 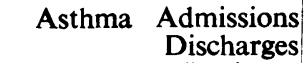 & $\begin{array}{l}8 \cdot 54 \\
5 \cdot 70\end{array}$ & $\begin{array}{l}4 \cdot 81 \\
3.83\end{array}$ & $\begin{array}{l}6 \cdot 05 \\
5 \cdot 35\end{array}$ & $\begin{array}{l}8 \cdot 96 \\
8 \cdot 01\end{array}$ & $\begin{array}{r}10 \cdot 53 \\
8 \cdot 10\end{array}$ & $\begin{array}{r}8 \cdot 13 \\
10 \cdot 22\end{array}$ & $\begin{array}{r}9 \cdot 70 \\
10 \cdot 66\end{array}$ & $\begin{array}{l}93 \\
72\end{array}$ & $\begin{array}{l}08 \\
95\end{array}$ & 28 & & \\
\hline $\begin{array}{l}\text { Neoplasms (benign } \\
\text { and unspecified) }\end{array}$ & & & & & & & 1000 & 14.12 & & 10 & & \\
\hline 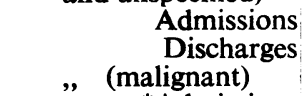 & $\begin{array}{r}11 \cdot 63 \\
3 \cdot 87\end{array}$ & $\begin{array}{l}6 \cdot 37 \\
3 \cdot 76\end{array}$ & $\begin{array}{l}7 \cdot 94 \\
3 \cdot 47\end{array}$ & $\begin{array}{l}8 \cdot 59 \\
8 \cdot 27\end{array}$ & $\begin{array}{l}8 \cdot 86 \\
3 \cdot 16\end{array}$ & $\begin{array}{r}10 \cdot 71 \\
8 \cdot 25\end{array}$ & $\begin{array}{r}10 \cdot 06 \\
9 \cdot 60\end{array}$ & $\begin{array}{l}11 \cdot 91 \\
14 \cdot 60\end{array}$ & $\begin{array}{l}11 \cdot 82 \\
18 \cdot 69\end{array}$ & $\begin{array}{l}12 \cdot 10 \\
26 \cdot 32\end{array}$ & & 10 \\
\hline $\begin{array}{r}\text { *Admissions } \\
\text { Discharges }\end{array}$ & $\begin{array}{l}1 \cdot 88 \\
2 \cdot 06\end{array}$ & $\begin{array}{l}2 \cdot 72 \\
1 \cdot 73\end{array}$ & $\begin{array}{l}3 \cdot 41 \\
1 \cdot 99\end{array}$ & $\begin{array}{l}4 \cdot 44 \\
2 \cdot 31\end{array}$ & $\begin{array}{l}5 \cdot 67 \\
4 \cdot 81\end{array}$ & $\begin{array}{l}7 \cdot 63 \\
6 \cdot 75\end{array}$ & $\begin{array}{r}10 \cdot 01 \\
9 \cdot 23\end{array}$ & $\begin{array}{l}13 \cdot 16 \\
14 \cdot 61\end{array}$ & $\begin{array}{l}23 \cdot 19 \\
24 \cdot 20\end{array}$ & \begin{tabular}{|}
$27 \cdot 88$ \\
$32 \cdot 32$
\end{tabular} & & \\
\hline Hernia $\begin{array}{r}\text { Admissions } \\
{ }^{*} \text { Discharges }\end{array}$ & $\begin{array}{r}12 \cdot 37 \\
0 \cdot 39\end{array}$ & $\begin{array}{l}7 \cdot 63 \\
0 \cdot 31\end{array}$ & $\begin{array}{l}7 \cdot 39 \\
0 \cdot 47\end{array}$ & $\begin{array}{l}8 \cdot 42 \\
1 \cdot 24\end{array}$ & $\begin{array}{l}9 \cdot 46 \\
1 \cdot 67\end{array}$ & $\begin{array}{r}11 \cdot 02 \\
2.91\end{array}$ & $\begin{array}{r}12 \cdot 32 \\
5 \cdot 31\end{array}$ & $\begin{array}{l}12 \cdot 15 \\
10 \cdot 04\end{array}$ & $\begin{array}{l}11 \cdot 03 \\
14 \cdot 56\end{array}$ & $\begin{array}{r}8 \cdot 22 \\
63 \cdot 10\end{array}$ & & 36 \\
\hline $\begin{array}{l}\text { D. Psychiatric and } \\
\text { Nervous disorders: }\end{array}$ & & & & & & & & & & & & \\
\hline $\begin{array}{l}\text { Sciatica Admissions } \\
\text { Discharges } \\
\text { Schizophrenia }\end{array}$ & $\begin{array}{l}1 \cdot 72 \\
1 \cdot 41\end{array}$ & $\begin{array}{l}2 \cdot 68 \\
1 \cdot 90\end{array}$ & $\begin{array}{l}4 \cdot 67 \\
2 \cdot 32\end{array}$ & $\begin{array}{l}7 \cdot 55 \\
3 \cdot 42\end{array}$ & $\begin{array}{l}9 \cdot 47 \\
5.95\end{array}$ & $\begin{array}{r}11.05 \\
7.96\end{array}$ & $\begin{array}{l}12 \cdot 83 \\
12.44\end{array}$ & $\begin{array}{l}16 \cdot 68 \\
20 \cdot 36\end{array}$ & $\begin{array}{l}18.94 \\
18.91\end{array}$ & $\begin{array}{l}14 \cdot 41 \\
25 \cdot 31\end{array}$ & $\begin{array}{l}100 \cdot 00 \\
100 \cdot 00\end{array}$ & 1,46 \\
\hline $\begin{array}{r}\text { Admissions } \\
\text { Discharges } \\
\text { Paranoid state }\end{array}$ & $\begin{array}{l}21 \cdot 18 \\
18 \cdot 66\end{array}$ & $\begin{array}{l}15 \cdot 39 \\
12 \cdot 84\end{array}$ & $\begin{array}{l}9 \cdot 85 \\
9 \cdot 89\end{array}$ & $\begin{array}{l}9 \cdot 48 \\
8 \cdot 63\end{array}$ & $\begin{array}{l}9 \cdot 48 \\
9 \cdot 60\end{array}$ & $\begin{array}{r}10 \cdot 34 \\
8 \cdot 79\end{array}$ & \begin{tabular}{l|l}
$8 \cdot 13$ \\
$9 \cdot 28$
\end{tabular} & $\begin{array}{l}8 \cdot 13 \\
8 \cdot 92\end{array}$ & $\begin{array}{l}5.42 \\
5: 89\end{array}$ & $\begin{array}{l}2 \cdot 59 \\
7 \cdot 49\end{array}$ & $\begin{array}{l}100 \cdot 00 \\
100 \cdot 00\end{array}$ & $1,01 \pi$ \\
\hline $\begin{array}{r}\text { Admissions } \\
\text { *Discharges } \\
\text { Manic depressive }\end{array}$ & $\begin{array}{l}0.44 \\
0.21\end{array}$ & $\begin{array}{l}1 \cdot 33 \\
1 \cdot 16\end{array}$ & $\begin{array}{l}1.43 \\
1.25\end{array}$ & $\begin{array}{l}3 \cdot 95 \\
4 \cdot 72\end{array}$ & $\begin{array}{c}7 \cdot 36 \\
4 \cdot 19\end{array}$ & $\begin{array}{l}6.02 \\
5.66\end{array}$ & $\begin{array}{l}11 \cdot 65 \\
11 \cdot 18\end{array}$ & $\begin{array}{l}21 \cdot 63 \\
14 \cdot 23\end{array}$ & $\begin{array}{l}17 \cdot 58 \\
31 \cdot 94\end{array}$ & $\begin{array}{l}28 \cdot 59 \\
25 \cdot 45\end{array}$ & $\begin{array}{l}100 \cdot 00 \\
100 \cdot 00\end{array}$ & \\
\hline $\begin{array}{r}\text { Admissions } \\
\text { Discharges }\end{array}$ & $\begin{array}{l}4 \cdot 25 \\
3 \cdot 24\end{array}$ & $\begin{array}{l}6 \cdot 14 \\
3 \cdot 83\end{array}$ & $\begin{array}{l}6 \cdot 85 \\
4 \cdot 68\end{array}$ & $\begin{array}{l}7 \cdot 95 \\
6 \cdot 33\end{array}$ & $\begin{array}{l}8 \cdot 43 \\
7 \cdot 61\end{array}$ & $\begin{array}{l}9 \cdot 84 \\
9 \cdot 83\end{array}$ & $\begin{array}{l}12 \cdot 13 \\
12 \cdot 27\end{array}$ & \begin{tabular}{|l|}
15.59 \\
17.44
\end{tabular} & $\begin{array}{l}15.83 \\
16.91\end{array}$ & $\begin{array}{l}12 \cdot 99 \\
17 \cdot 86\end{array}$ & $\begin{array}{l}100 \cdot 00 \\
100 \cdot 00\end{array}$ & $992 \sigma$ \\
\hline $\begin{array}{r}\text { state } \\
\text { Admissions } \\
\text { Discharges }\end{array}$ & $\begin{array}{l}5 \cdot 83 \\
2 \cdot 91\end{array}$ & $\begin{array}{l}7 \cdot 92 \\
3 \cdot 54\end{array}$ & $\begin{array}{l}8 \cdot 93 \\
4 \cdot 57\end{array}$ & $\begin{array}{l}9 \cdot 74 \\
5 \cdot 71\end{array}$ & $\begin{array}{r}10 \cdot 11 \\
7 \cdot 11\end{array}$ & $\begin{array}{r}10.75 \\
9.09\end{array}$ & $\begin{array}{l}12.02 \\
11.04\end{array}$ & $\begin{array}{l}13 \cdot 11 \\
16 \cdot 00\end{array}$ & $\begin{array}{l}13 \cdot 93 \\
19 \cdot 33\end{array}$ & $\begin{array}{r}7 \cdot 65 \\
20 \cdot 70\end{array}$ & & 6,458 \\
\hline $\begin{array}{r}\text { Hysteria Admissions } \\
\text { Discharges } \\
\text { Ill psychiatric disorders }\end{array}$ & $\begin{array}{r}15.03 \\
8.68\end{array}$ & $\begin{array}{r}10.05 \\
5.01\end{array}$ & $\begin{array}{l}8 \cdot 68 \\
5 \cdot 36\end{array}$ & $\begin{array}{l}9 \cdot 42 \\
6 \cdot 36\end{array}$ & $\begin{array}{r}10 \cdot 79 \\
8.00\end{array}$ & $\begin{array}{l}9 \cdot 52 \\
9 \cdot 33\end{array}$ & $\begin{array}{l}10 \cdot 16 \\
10 \cdot 76\end{array}$ & $\begin{array}{r}9.21 \\
15.07\end{array}$ & \begin{tabular}{|l|}
10.79 \\
19.07
\end{tabular} & $\begin{array}{r}6 \cdot 35 \\
12 \cdot 36\end{array}$ & $\begin{array}{l}100 \cdot 00 \\
100 \cdot 00\end{array}$ & $\begin{array}{l}2,908 \mathrm{D} \\
3,282\end{array}$ \\
\hline $\begin{array}{l}\text { Admissions } \\
\text { Discharges }\end{array}$ & $\begin{array}{l}6 \cdot 02 \\
6 \cdot 73\end{array}$ & $\begin{array}{l}5 \cdot 74 \\
5 \cdot 05\end{array}$ & $5 \cdot 48$ & $\begin{array}{l}7 \cdot 93 \\
6 \cdot 38\end{array}$ & $\begin{array}{l}8 \cdot 71 \\
7 \cdot 40\end{array}$ & $\begin{array}{l}9 \cdot 88 \\
8 \cdot 97\end{array}$ & $\begin{array}{l}11 \cdot 67 \\
10 \cdot 80\end{array}$ & $\begin{array}{l}14 \cdot 12 \\
14 \cdot 85\end{array}$ & $\begin{array}{l}16 \cdot 76 \\
17 \cdot 95\end{array}$ & $\begin{array}{l}12 \cdot 77 \\
16 \cdot 38\end{array}$ & $\begin{array}{l}100 \cdot 00 \\
100 \cdot 00\end{array}$ & \\
\hline
\end{tabular}


Though discharge and hospitalization distributions for the peptic ulcers agree closely, striking discrepancies between the two distributions with respect to other diseases call for explanation. That the incidence of bronchitis among discharges increases more steeply with age than that of hospital cases is not surprising. Since the latter are far in excess of the former, we may infer that discharge with reference to chronic bronchitis includes only more serious cases among those represented by hospital admissions. The fact that it is a steadily progressive disease and the greater likelihood of emphysema among the oldest age groups might well suffice to account for the observed disparity; but greater reluctance to recommend for discharge younger soldiers may well contribute thereto. Since asthma depends on a congenital diathesis which may become manifest at an early age, it is not surprising that it exhibits no striking age-incidence trend among hospital admissions. That it shows increasing relative frequency with advancing age among medical discharges is possibly explicable in terms of administrative rather than of clinical considerations. As regards hernia we are on firmer ground. It is beyond dispute that the two sets of figures in Table IX refer to totally different categories. Whereas those for hospital admission refer exclusively to cases admitted for operation, mostly to first operations, those for medical discharges refer either to individuals who have not submitted to operative treatment or to recurrent cases. A similar discrepancy between hospital admission and discharge distributions with reference to benign neoplasms scarcely calls for explanation, since conditions so specified are very diverse with respect both to their nature and to their severity. The discharge data refer only to a small fraction of hospital cases, presumably the more grave.

With minor differences which are not surprising, age distributions of psychiatric disorders based on hospital admissions show the same features as those based on discharge from service. For United Kingdom hospital admissions with reference to schizophrenia the characteristic trend is more uniform than for medical discharges from the service. Since the number of United Kingdom cases hospitalized with respect to manic depressive psychosis exceeds discharges for the whole Army during the period covered, this diagnosis cannot of itself be a sufficient ground for discharge at the first diagnosis, and it is well known that its manifestations are liable to recur with increasing severity. Presumably these considerations account in large measure for a disparity between the two distributions cited in Table IX, i.e. (a) hospital admissions show a peak at about 44 years of age; (b) liability to discharge from service increases to the limit of the age range. A corresponding but more striking disparity emerges from comparison of the two sets of figures for anxiety state. The three conditions named, together with paranoid state, each have the facies of a clear-cut clinical phenomenon in so far as the age-incidence distribution discloses a uniform trend. The same is not true of obsessional psychoneurosis, of hysteria, of neurasthenia nor (needless to say) of so-called psychopathic personality.

Age-Incidence in the Female Population. With respect to most diseases A.T.S. 
TABLE X

Relative Age-Incidence Distributions of Admissions to Hospital in the U.K.; A.T.S. Auxiliaries

\begin{tabular}{|c|c|c|c|c|c|c|c|c|c|c|c|}
\hline & $<22$ & $22-24$ & $25-27$ & $28-30$ & $31-33$ & $|34-36|$ & $|37-39|$ & $>39$ & Total & $\left|\begin{array}{l}\text { Size of } \\
\text { Sample }\end{array}\right|$ & $\mathbf{Q}$ \\
\hline \multicolumn{12}{|l|}{$\begin{array}{l}\text { A. Communicable } \\
\text { Diseases: }\end{array}$} \\
\hline \\
\hline $\begin{array}{l}\text { (excl. pleurisy) } \\
\text { T.B. at other sites }\end{array}$ & $\begin{array}{l}12 \cdot 72 \\
15 \cdot 69\end{array}$ & $\begin{array}{l}13 \cdot 79 \\
16 \cdot 74\end{array}$ & $\begin{array}{l}16 \cdot 47 \\
13 \cdot 12\end{array}$ & $\begin{array}{r}14.99 \\
9.65\end{array}$ & $\begin{array}{l}8 \cdot 84 \\
5 \cdot 73\end{array}$ & $\begin{array}{r}20 \cdot 35 \\
9 \cdot 80\end{array}$ & $\begin{array}{r}7 \cdot 50 \\
29 \cdot 26\end{array}$ & $5 \cdot 35$ & $\begin{array}{l}100 \cdot 00 \\
100 \cdot 00\end{array}$ & $\begin{array}{r}161 \\
94\end{array}$ & $\begin{array}{l}13 \cdot 39 \\
15 \cdot 08\end{array}$ \\
\hline$n$ & $13 \cdot 79$ & 16 & & 13. & 7 & 1 & 14.90 & 3.48 & & & \\
\hline $\begin{array}{l}\text { ple } \\
\text { Diph }\end{array}$ & $26 \cdot 24$ & 3.28 & 3.66 & 20.43 & 4.09 & 1 & $14 \cdot 90$ & $\begin{array}{l}3.48 \\
7.31\end{array}$ & 10 & $\begin{array}{l}253 \\
191\end{array}$ & 21 \\
\hline \multicolumn{12}{|l|}{ Dysentery - } \\
\hline${ }^{*}$ Chic & 29.56 & $\begin{array}{r}22.01 \\
7.61\end{array}$ & $16 \cdot 81$ & $15 \cdot 75$ & $\begin{array}{l}0.01 \\
7.79\end{array}$ & $\begin{array}{r}10.44 \\
7.08\end{array}$ & 10.36 & $\overline{15 \cdot 40}$ & & $\begin{array}{l}111 \\
155\end{array}$ & $\begin{array}{l}18 \cdot 98 \\
17 \cdot 70\end{array}$ \\
\hline *Glar & 89 & $6 \cdot 39$ & $19 \cdot 67$ & $12 \cdot 13$ & $15 \cdot 74$ & $19 \cdot 18$ & & & & 106 & $16 \cdot 39$ \\
\hline Mea & 2 & $6 \cdot 29$ & $16 \cdot 13$ & $6 \cdot 45$ & $15 \cdot 16$ & $3 \cdot 23$ & $14 \cdot 52$ & $13 \cdot 71$ & & & 16. \\
\hline Mu & & $9 \cdot 02$ & 23. & $17 \cdot 86$ & $6 \cdot 26$ & - & - & $17 \cdot 13$ & & & \\
\hline $\mathbf{R}$ & & 5 & 6 & $6 \cdot 42$ & $11 \cdot 18$ & $14 \cdot 49$ & - & $10 \cdot 14$ & & & \\
\hline Sca & $28 \cdot 41$ & $10 \cdot 36$ & 3.05 & $16 \cdot 89$ & $9 \cdot 98$ & $8 \cdot 64$ & $12 \cdot 67$ & - & & & 19 \\
\hline \multirow{2}{*}{\multicolumn{4}{|c|}{ Otitis media- }} & $21 \cdot 13$ & $9 \cdot 46$ & & $3 \cdot 42$ & $2 \cdot 41$ & 100.00 & 534 & \\
\hline & $17 \cdot 31$ & $9 \cdot 26$ & $21 \cdot 91$ & $21 \cdot 91$ & $5 \cdot 48$ & & $14 \cdot 14$ & - & & 3 & 17 \\
\hline Sinusitis-all & 8 & & & $14 \cdot 32$ & $21 \cdot 04$ & $14 \cdot 58$ & & $11 \cdot 41$ & & & \\
\hline Pneur & 5 & $9 \cdot 62$ & $5 \cdot 33$ & $12 \cdot 86$ & $9 \cdot 71$ & $39 \cdot 33$ & $8 \cdot 29$ & 5.90 & & 104 & \\
\hline 0 & $19 \cdot 07$ & 2.06 & 11.92 & $8 \cdot 88$ & - & 28.06 & - & $30 \cdot 01$ & & & \\
\hline Infective h & $16 \cdot 44$ & $14 \cdot 65$ & $12 \cdot 71$ & $11 \cdot 96$ & $\mid 12 \cdot 41$ & $15 \cdot 25$ & $13 \cdot 45$ & $3 \cdot 14$ & $100 \cdot 00$ & 302 & 14. \\
\hline .. & $19 \cdot 69$ & $11 \cdot 08$ & $12 \cdot 77$ & $9 \cdot 38$ & $16 \cdot 77$ & - & 一 & $30 \cdot 31$ & $100 \cdot 00$ & 98 & $15 \cdot 38$ \\
\hline $\begin{aligned} \text { Gono } \\
\text { pri }\end{aligned}$ & $16 \cdot 18$ & 5 & $11 \cdot 27$ & $12 \cdot 72$ & $21 \cdot 10$ & $13 \cdot 58$ & - & 11.99 & & 390 & 14 \\
\hline Scab & $33 \cdot 41$ & & $11 \cdot 29$ & $10 \cdot 14$ & 8.99 & $10 \cdot 14$ & $7 \cdot 60$ & 1.84 & & 829 & \\
\hline Impet & $33 \cdot 67$ & $19 \cdot 39$ & $14 \cdot 54$ & 10.97 & $2 \cdot 81$ & $4 \cdot 59$ & $\mid 14.03$ & - & $100 \cdot 00$ & 328 & $25 \cdot 51$ \\
\hline \multicolumn{12}{|l|}{ C. Other Organic } \\
\hline $\begin{array}{c}\text { Disorders: } \\
\text { Appendicitis }\end{array}$ & $22 \cdot 02$ & $16 \cdot 33$ & $17 \cdot 25$ & $13 \cdot 94$ & $7 \cdot 89$ & $8 \cdot 62$ & 10.09 & $3 \cdot 85$ & $100 \cdot 00$ & 1,821 & $18 \cdot 35$ \\
\hline $\begin{array}{l}\text { Bronc } \\
\text { chr } \\
\text { Asthn }\end{array}$ & $\begin{array}{r}3 \cdot 65 \\
15 \cdot 55\end{array}$ & $\begin{array}{l}5 \cdot 45 \\
5 \cdot 74\end{array}$ & $\begin{array}{r}7 \cdot 30 \\
14 \cdot 95\end{array}$ & $\begin{array}{r}8 \cdot 41 \\
12 \cdot 80\end{array}$ & $\begin{array}{r}7 \cdot 42 \\
14 \cdot 47\end{array}$ & $\begin{array}{r}19 \cdot 25 \\
7 \cdot 18\end{array}$ & $\begin{array}{r}4 \cdot 75 \\
10 \cdot 53\end{array}$ & $\begin{array}{l}43 \cdot 77 \\
18 \cdot 78\end{array}$ & & $\begin{array}{l}111 \\
206\end{array}$ & $\begin{array}{r}5 \cdot 80 \\
11.96\end{array}$ \\
\hline $\begin{array}{l}\text { Neoplasms (benign } \\
\text { and unspecified) }\end{array}$ & $7 \cdot 15$ & $3 \cdot 86$ & $9 \cdot 40$ & $7 \cdot 78$ & $11 \cdot 78$ & $17 \cdot 67$ & $18 \cdot 30$ & $24 \cdot 05$ & $100 \cdot 00$ & 488 & $7 \cdot 01$ \\
\hline \multicolumn{12}{|l|}{ D. Psychiatric and } \\
\hline Schi & $7 \cdot 61$ & $5 \cdot 26$ & $13 \cdot 20$ & $11 \cdot 42$ & $14 \cdot 41$ & $19 \cdot 84$ & $7 \cdot 37$ & $20 \cdot 89$ & $100 \cdot 00$ & 100 & $8 \cdot 10$ \\
\hline $\begin{array}{l}\text { Psyc } \\
\text { pe }\end{array}$ & $\cdot 4$ & $5 \cdot 95$ & $12 \cdot 73$ & $15 \cdot 15$ & $14 \cdot 87$ & $25 \cdot 65$ & - & $16 \cdot 17$ & $100 \cdot 00$ & 111 & $9 \cdot 29$ \\
\hline essive & $6 \cdot 6$ & $7 \cdot$ & $7 \cdot 41$ & 14 & 16 . & 13. & $24 \cdot 80$ & $8 \cdot 70$ & & 177 & $8 \cdot($ \\
\hline Anxiety state & & 10 & 9. & 12. & $14 \cdot 94$ & & & 19 & & & \\
\hline Hys & & & st & $15 \cdot 07$ & $8 \cdot 53$ & $20 \cdot 27$ & $13 \cdot 73$ & $5 \cdot 87$ & & 444 & $13 \cdot 33$ \\
\hline
\end{tabular}

* Sample includes 1944 cases. 
hospital admissions for a single year (Table $\mathrm{X}$ ) are relatively few, and, since the age composition of the population at risk is very skew, the computed relative incidence of the older age groups is liable to considerable variation. With due regard to these considerations, previous remarks with reference to communicable diseases (and to appendicitis) apply equally to males and to females. There is oneapparent exception to this statement, namely infective hepatitis. Among women the incidence of this disease does not appear to fall off conspicuously with age. This may be partly due to the fact that it is much less common among women than among men, though

TABLE XI

MALE STANDARDizing FACTORS With RESPECT to U.K. Hospital Admissions

(A.T.S. as standard population)

\begin{tabular}{|c|c|c|c|c|}
\hline & & & 1943 & 1944 \\
\hline $\begin{array}{l}\text { Scarlet fever } \\
\text { T.B. pulmonary } \\
\text { T.B. at other sites } \\
\text { Infective hepatitis } \\
\text { Impetigo . . } \\
\text { Tonsillitis . } \\
\text { Pneumonia . } \\
\text { Chronic bronchitis } \\
\text { Otitis media } \\
\text { Gonorrhoea } \\
\text { Syphilis ... } \\
\text { Hernia . } \\
\text { Appendicitis .. } \\
\text { Asthma . . } \\
\text { Peptic ulcer-all } \\
\text { Gastric ulcer } \\
\text { Duodenal ulcer } \\
\text { Nephritis . } \\
\text { All psychiatric disor } \\
\text { All other diseases }\end{array}$ & $\begin{array}{l}\because \\
\because \\
\because \\
\because \\
\because \\
\because \\
\because \\
\because \\
\because \\
\because \\
\because \\
\because \\
\because \\
\ddot{d e r s} \\
. .\end{array}$ & $\begin{array}{l}. \\
\therefore \\
\therefore \\
\therefore \\
\therefore \\
\therefore \\
\therefore \\
\therefore \\
\therefore\end{array}$ & $\begin{array}{l}1.569 \\
0.984 \\
1.235 \\
1.223 \\
1.496 \\
1.166 \\
1.204 \\
0.544 \\
1.135 \\
0.994 \\
0.957 \\
1.044 \\
1.343 \\
0.880 \\
0.531 \\
0.475 \\
0.540 \\
0.957 \\
0.800 \\
1.032\end{array}$ & $\begin{array}{l}1.409 \\
0.957 \\
1.178 \\
1.243 \\
1.437 \\
1.130 \\
1.097 \\
0.509 \\
1.128 \\
1.066 \\
0.992 \\
0.982 \\
1.305 \\
0.814 \\
0.528 \\
0.468 \\
0.540 \\
0.937 \\
0.772 \\
1.000\end{array}$ \\
\hline All diseases .. & $\cdots$ & & 042 & $1 \cdot 012$ \\
\hline
\end{tabular}

conceivably also to a sex-difference with respect to the power of the body to react to the virus antigen. Male and female distributions of scabies, each referable to large samples, reveal a striking difference which may well be spurious. A high proportion of patients do not receive hospital treatment, and the male sample almost certainly contains a higher proportion of intractable cases, which inflate incidence in the older segment of the population. The only psychiatric disorders for which A.T.S. samples are large enough to justify confidence exhibit no features other than those which the discharge data disclose. One feature worthy of comment in Table $X$ is a dip in the 22-24 age group of virus diseases, scarlet fever and tonsillitis. 
A similar dip is evident in the figures of Table VIII, where it might otherwise provoke the suspicion that our estimate of the relative strength of this age group in the 1943 United Kingdom Army population is somewhat excessive.

Sex Differentials. The data in Table VIII provide a basis for standardization of figures referable to populations of different age composition. If our aim is to assess sex differences with respect to morbidity, it comes to the same thing to ask either $(a)$ what the female rate would be if, with its own age-incidence distribution, the age-strength distribution were that of the male population in the same year or (b) what the male rate would be if, with its own age-incidence distribution, its age-strength distribution were that of the female population in the same year. Since we have larger samples for the male population, the second is preferable.

TABLE XII

Relative Streṇgth-Age Distributions

\begin{tabular}{|c|c|c|c|c|c|c|c|c|c|c|c|}
\hline 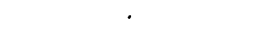 & $<22$ & $22-24$ & $25-27$ & $28-30$ & $31-33$ & $34-36$ & $37-39$ & $40-42$ & $43-45$ & $>45$ & Total \\
\hline $\begin{array}{c}\text { Known whole Army } \\
1943-1944\end{array}$ & $14 \cdot 04$ & $17 \cdot 92$ & $16 \cdot 66$ & $15 \cdot 79$ & $13 \cdot 52$ & $9 \cdot 48$ & $6 \cdot 67$ & 3.98 & $1 \cdot 12$ & 0.82 & 100.0 \\
\hline Estimated U.K. & & & & & & & 0.01 & & & & 1000 \\
\hline $\begin{array}{l}\text { 1943-1944 } \\
\text { Known C.M.F. mid- }\end{array}$ & $15 \cdot 79$ & $15 \cdot 87$ & $15 \cdot 19$ & $14 \cdot 81$ & $\cdot 40$ & $9 \cdot 93$ & $7 \cdot 49$ & $4 \cdot 82$ & $1 \cdot 49$ & $1 \cdot 20$ & 100.00 \\
\hline Feb. 1945 & $7 \cdot 66$ & $19 \cdot 20$ & $19 \cdot 96$ & $17 \cdot 08$ & $14 \cdot 27$ & $10 \cdot 50$ & $6 \cdot 94$ & $3 \cdot 07$ & $1 \cdot 07$ & 0.25 & $100 \cdot 00$ \\
\hline $\begin{array}{l}\text { Known M.E.F. mid- } \\
\text { Feb. 1945 }\end{array}$ & $4 \cdot 66$ & $15 \cdot 66$ & $21 \cdot 33$ & $19 \cdot 82$ & $14 \cdot 78$ & $11 \cdot 01$ & $7 \cdot 23$ & $3 \cdot 60$ & $1 \cdot 49$ & 0.42 & $100 \cdot 00$ \\
\hline $\begin{array}{l}\text { Estimated M.E. } \\
\text { 1943-1944 }\end{array}$ & $5 \cdot 00$ & $21 \cdot 50$ & $20 \cdot 00$ & $17 \cdot 00$ & $14 \cdot 00$ & $10 \cdot 50$ & $7 \cdot 00$ & $3 \cdot 40$ & $1 \cdot 10$ & $0 \cdot 50$ & $100 \cdot 00$ \\
\hline
\end{tabular}

Table XI shows some standardizing factors computed on this basis. To say that the military (male) standardizing factor with reference to A.T.S. strength for gastric ulcer in the year 1944 is 0.468 means that it is necessary to multiply the male incidence in that year by 0.468 to make it comparable with the female incidence of the same year, with the implication that differences with reference to age composition of the two populations do not then affect conclusions drawn from such a comparison.

The sex difference already noted with respect to the incidence of peptic ulcers merits further comment in this context. In the female population the total annual ' number of peptic ulcers specified as such is small. In 1943 there were 50 hospital admissions and 61 discharges from the service. The ratio of duodenal to gastric ulcers based on the breakdown of these figures is very much smaller than the corresponding ratio for males. Though the female sample is small, the difference is worth recording, because the effect of age standardization is to reinforce the impression derived from the crude figures. 
RELATION OF MORBIDITY TO AGE IN AN ARMY POPULATION 175

Ratios of Duopenai to Gastric Ulcers

\begin{tabular}{|c|c|c|c|c|c|c|}
\hline \multirow{2}{*}{\multicolumn{7}{|c|}{ Females }} \\
\hline & & & & & & \\
\hline Crude & .. & .. & .. & .. & $4 \cdot 7$ & $2 \cdot 5$ \\
\hline Standardized & .. & .. & .. & .. & $5 \cdot 4$ & $2 \cdot 5$ \\
\hline Hospital admissions & & & & & & \\
\hline Crude & .. & .. & .. & .. & 3.9 & 1.9 \\
\hline Standardized & .. & .. & .. & .. & $4 \cdot 4$ & $1 \cdot 9$ \\
\hline
\end{tabular}

These figures suggest the conclusion that the excessive incidence of peptic ulcers in the male Army population is largely due to greater liability of the male to the duodenal type, which is the more common of the two. Without more data, this must remain a suggestion. It would be interesting to know how relative liability to one or other type is related to occupation.

TABLE XIII

\begin{tabular}{|c|c|c|c|c|c|c|c|c|c|c|c|c|c|}
\hline & & $<22$ & $22-24$ & $25-27$ & $28-30$ & $31-33$ & $34-36$ & $37-39$ & $40-42$ & $43-45$ & $>45$ & Total & $\begin{array}{c}\text { Sample } \\
\text { size }\end{array}$ \\
\hline $\begin{array}{l}\text { Duodenal } \\
\text { ulcer }\end{array}$ & $\begin{array}{l}\mathbf{A} \\
\mathbf{B} \\
\mathbf{C}\end{array}$ & $\begin{array}{l}1 \cdot 45 \\
2 \cdot 76 \\
2 \cdot 21\end{array}$ & $\begin{array}{l}1 \cdot 74 \\
1 \cdot 93 \\
3 \cdot 33\end{array}$ & $\begin{array}{l}3 \cdot 29 \\
4 \cdot 08 \\
4 \cdot 59\end{array}$ & $\begin{array}{l}4 \cdot 09 \\
5 \cdot 09 \\
7 \cdot 35\end{array}$ & $\begin{array}{l}4 \cdot 89 \\
6 \cdot 18 \\
8 \cdot 78\end{array}$ & $\begin{array}{r}7 \cdot 13 \\
8 \cdot 84 \\
10 \cdot 96\end{array}$ & $\begin{array}{r}9 \cdot 48 \\
11 \cdot 65 \\
13 \cdot 21\end{array}$ & \begin{tabular}{|l|}
$12 \cdot 52$ \\
$14 \cdot 02$ \\
$16 \cdot 76$
\end{tabular} & $\begin{array}{l}18 \cdot 93 \\
22 \cdot 83 \\
17 \cdot 49\end{array}$ & $\begin{array}{l}36 \cdot 47 \\
22 \cdot 61 \\
15 \cdot 30\end{array}$ & $\begin{array}{l}100 \cdot 00 \\
100 \cdot 00 \\
100.00\end{array}$ & $\begin{array}{r}453 \\
453 \\
4,665\end{array}$ \\
\hline $\begin{array}{r}\text { Gastric } \\
\text { ulcer }\end{array}$ & $\begin{array}{l}\mathbf{A} \\
\mathbf{B} \\
\mathbf{C}\end{array}$ & $\begin{array}{l}1 \cdot 32 \\
2 \cdot 80 \\
1 \cdot 51\end{array}$ & $\begin{array}{l}1 \cdot 93 \\
2 \cdot 39 \\
1.98\end{array}$ & $\begin{array}{l}2 \cdot 70 \\
3 \cdot 73 \\
2 \cdot 71\end{array}$ & $\begin{array}{l}2 \cdot 56 \\
3 \cdot 57 \\
4 \cdot 34\end{array}$ & $\begin{array}{l}4 \cdot 25 \\
6 \cdot 01 \\
5 \cdot 90\end{array}$ & $\begin{array}{r}7 \cdot 70 \\
10 \cdot 67 \\
9 \cdot 75\end{array}$ & $\begin{array}{r}9 \cdot 22 \\
12 \cdot 67 \\
12 \cdot 61\end{array}$ & $\begin{array}{l}13 \cdot 17 \\
.16 \cdot 49 \\
16 \cdot 71\end{array}$ & $\begin{array}{r}3 \cdot 16 \\
4 \cdot 27 \\
19 \cdot 38\end{array}$ & \begin{tabular}{|l|}
$53 \cdot 98$ \\
$37 \cdot 40$ \\
$25 \cdot 12$
\end{tabular} & $\begin{array}{l}100.00 \\
100.00 \\
100.00\end{array}$ & $\begin{array}{l}121 \\
121 \\
995\end{array}$ \\
\hline
\end{tabular}

6. Relation of Age to Hospital admissions in the Middle East

The preceding section has emphasized a striking dichotomy with respect to the risk of specific diseases at different ages. With a few exceptions seemingly consistent with such an explanation, diminishing frequency of communicable diseases as age increases is interpretable on the assumption that immunization by previous attack progressively reduces the effective, as opposed to the apparent, population at risk. Such a progressive reduction will not occur if previous attacks confer little immunity and it will not be relevant to the age-risk relation if the disease is: (a) extremely rare; (b) highly fatal; (c) absent in the original habitat of a newly immigrant population. The first two limitations have been the subject of earlier comment. Morbidity experience of an Army population serving overseas offers an opportunity of testing the general hypothesis stated above by reference to the third $(c)$, as an independent check.

Hospital admission records of troops serving in the Middle East during 1943-4 furnish large samples for this purpose; but analysis of such records again confronts us with the difficulty of assessing the exact population at risk in different age groups, because our first available information for the exact age composition of an overseas 
force refers to the beginning of 1945. At that time conditions in the Middle East were very different from such as existed in 1943, when fighting was in progress. We have therefore made an estimate of the age composition of the M.E.F. in 1943-4 by the method of adjusting the figures for the Army as a whole in such a way as to bring the age-incidence distribution of certain marker diseases into close correspondence with the known distribution of these diseases among medical discharges. This adjusted distribution, referred to as estimated M.E.F. 1943-1944 at the foot of Table XII, and hereinafter used as a basis for the age-incidence distributions indicated as $B$, tallies more closely with the known early 1945 age composition of the Central Mediterranean Force than with that of M.E.F. at the same date. This is not remarkable, since large numbers of Middle East troops were transferred to C.M.F. at the end of the Middle East campaign. We shall

TABLE XIV

\begin{tabular}{|c|c|c|c|c|c|c|c|c|c|c|c|c|}
\hline & $<22$ & $22-24$ & 25-27 & $28-30$ & $31-33$ & $34-36$ & $37-39$ & $40-42$ & $43-45$ & $>45$ & Total & $\begin{array}{l}\text { Sa mple } \\
\text { Size }\end{array}$ \\
\hline $\begin{array}{c}\text { Infective } \\
\text { hepatitis }\end{array}$ & \begin{tabular}{l|l}
$A$ & $14 \cdot 63$ \\
B & $22 \cdot 49$ \\
& $16 \cdot 28$
\end{tabular} & $\begin{array}{l}18.59 \\
16.67 \\
15.07\end{array}$ & $\begin{array}{l}13 \cdot 99 \\
14 \cdot 02 \\
13 \cdot 12\end{array}$ & $\begin{array}{l}10 \cdot 71 \\
10 \cdot 79 \\
12 \cdot 39\end{array}$ & $\begin{array}{r}8 \cdot 06 \\
8 \cdot 24 \\
10 \cdot 09\end{array}$ & $\begin{array}{l}6 \cdot 97 \\
7 \cdot 00 \\
8 \cdot 26\end{array}$ & $\begin{array}{l}5 \cdot 52 \\
5 \cdot 49 \\
7 \cdot 65\end{array}$ & $\begin{array}{l}5 \cdot 12 \\
4 \cdot 64 \\
6 \cdot 08\end{array}$ & $\begin{array}{l}5 \cdot 08 \\
4.96 \\
5 \cdot 83\end{array}$ & $\begin{array}{r}11 \cdot 34 \\
5 \cdot 69 \\
5 \cdot 22\end{array}$ & $\begin{array}{l}100 \cdot 00 \\
100 \cdot 00 \\
100 \cdot 00\end{array}$ & $\begin{array}{l}6,256 \\
6,256 \\
3,536\end{array}$ \\
\hline $\begin{array}{l}\text { Appendi- } \\
\text { citis }\end{array}$ & \begin{tabular}{l|l} 
& $15 \cdot 06$ \\
& $23 \cdot 30$ \\
& $21 \cdot 42$
\end{tabular} & $\begin{array}{l}14 \cdot 83 \\
13 \cdot 38 \\
13 \cdot 34\end{array}$ & $\begin{array}{l}11.57 \\
11.66 \\
10.53\end{array}$ & $\begin{array}{r}9 \cdot 58 \\
9.72 \\
10 \cdot 89\end{array}$ & $\begin{array}{r}8 \cdot 28 \\
8 \cdot 52 \\
10 \cdot 04\end{array}$ & $\begin{array}{l}6 \cdot 62 \\
6 \cdot 68 \\
8 \cdot 20\end{array}$ & $\begin{array}{l}7 \cdot 20 \\
7 \cdot 21 \\
8 \cdot 69\end{array}$ & $\begin{array}{l}5 \cdot 25 \\
4 \cdot 79 \\
7 \cdot 34\end{array}$ & $\begin{array}{l}8 \cdot 03 \\
7 \cdot 88 \\
5 \cdot 26\end{array}$ & $\begin{array}{r}13 \cdot 58 \\
6 \cdot 85 \\
4 \cdot 20\end{array}$ & $\begin{array}{l}100 \cdot 00 \\
100 \cdot 00 \\
100 \cdot 00\end{array}$ & $\begin{array}{l}1,847 \\
1,847 \\
4,874\end{array}$ \\
\hline
\end{tabular}

later refer to age incidence distributions, based upon the C.M.F. 1945 age composition, as estimate $\mathrm{A}$, and cite in Table $\mathrm{XV}$ age-incidence distributions with reference both to the actual age composition of C.M.F. in 1945 (A) and to the age composition of M.E.F. in 1943-1944 (B) computed in conformity with appropriate marker statistics.

As a background to the order of error arising from this uncertainty, Table XII shows relative sizes of the populations at risk in different age groups.

For comparison with the marker statistic (C) based on discharge figures shown in section 4 above, the following table (XIII) shows distributions of peptic ulcer based on different estimates of the M.E.F. strength: A, the known C.M.F. distribution at mid-February $1945 ; \mathrm{B}$, the corresponding adjusted distribution referred to in the previous table as "Estimated M.E.F. 1943-1944."

Since United Kingdom strength distributions used in the preceding section yield results in close agreement with those based on comparable discharge figures, we may also cite (Table XIV) United Kingdom distributions (D) of two other diseases as a check on the credentials of B and A. Again B tallies more closely with the marker statistic.

While it is clear that the use of estimate B gives results which more nearly correspond with the marker statistics cited, the following table (XV) gives 
distributions for diseases in M.E.F. on both estimates (A and B) of the population at risk in the several age groups.

To assess the propriety of any estimate we employ, it is necessary to give due consideration to the following issues. In view of circumstances relevant to selection of the youngest and oldest for service overseas at different stages of the

TABLE XV

Relative Age Incidence Distributions; Middle East, 1943-44

\begin{tabular}{|c|c|c|c|c|c|c|c|c|c|c|c|c|c|c|}
\hline & & $<22$ & $22-24$ & $25-27$ & $28-30$ & $31-33$ & $34-36$ & $37-39$ & $40-42$ & 43-45 & $>45$ & Total & $\begin{array}{c}\text { Sample } \\
\text { Size }\end{array}$ & $\mathbf{Q}$ \\
\hline $\begin{array}{c}\text { Malaria } \\
\text { B.T. }\end{array}$ & $\begin{array}{l}\mathbf{A} \\
\mathbf{B}\end{array}$ & $\begin{array}{r}9 \cdot 52 \\
15 \cdot 23\end{array}$ & $\begin{array}{l}13 \cdot 36 \\
12 \cdot 47\end{array}$ & $\begin{array}{l}11.46 \\
11.94\end{array}$ & $\begin{array}{l}11 \cdot 07 \\
11 \cdot 61\end{array}$ & $\begin{array}{r}9.42 \\
10.03\end{array}$ & $\begin{array}{l}8 \cdot 61 \\
8 \cdot 99\end{array}$ & $\begin{array}{l}7 \cdot 68 \\
7 \cdot 96\end{array}$ & $\begin{array}{l}8 \cdot 89 \\
8 \cdot 39\end{array}$ & $\begin{array}{l}5.96 \\
6 \cdot 05\end{array}$ & $\begin{array}{r}14.03 \\
7 \cdot 33\end{array}$ & $\begin{array}{l}100 \cdot 00 \\
100 \cdot 00\end{array}$ & $\begin{array}{l}13,443 \\
13,443\end{array}$ & $\begin{array}{l}10 \cdot 63 \\
11 \cdot 10\end{array}$ \\
\hline $\begin{array}{c}\text { Malaria } \\
\text { M.T. }\end{array}$ & $\begin{array}{l}\mathbf{A} \\
\mathbf{B}\end{array}$ & $\begin{array}{r}8 \cdot 61 \\
13.95\end{array}$ & $\begin{array}{l}14.68 \\
13.86\end{array}$ & $\begin{array}{l}11 \cdot 27 \\
11 \cdot 89\end{array}$ & $\begin{array}{l}9 \cdot 26 \\
9 \cdot 84\end{array}$ & $\begin{array}{l}8 \cdot 88 \\
9 \cdot 57\end{array}$ & $\begin{array}{l}8 \cdot 49 \\
8 \cdot 98\end{array}$ & $\begin{array}{l}8 \cdot 42 \\
8 \cdot 83\end{array}$ & $\begin{array}{l}9 \cdot 03 \\
8 \cdot 63\end{array}$ & $\begin{array}{l}6 \cdot 33 \\
6 \cdot 52\end{array}$ & $\begin{array}{r}15.02 \\
7.94\end{array}$ & $\begin{array}{l}100 \cdot 00 \\
100 \cdot 00\end{array}$ & $\begin{array}{l}1,392 \\
1,392\end{array}$ & $\begin{array}{l}10.43 \\
11.03\end{array}$ \\
\hline $\begin{array}{r}\text { Dysentery } \\
\text { Flexner }\end{array}$ & \begin{tabular}{l|l}
$\mathbf{A}$ \\
$\mathbf{B}$
\end{tabular} & $\begin{array}{l}16 \cdot 78 \\
25 \cdot 09\end{array}$ & $\begin{array}{r}11 \cdot 31 \\
9 \cdot 78\end{array}$ & $\begin{array}{l}8 \cdot 96 \\
8 \cdot 66\end{array}$ & $\begin{array}{l}9 \cdot 83 \\
9 \cdot 57\end{array}$ & $\begin{array}{l}8 \cdot 70 \\
8 \cdot 59\end{array}$ & $\begin{array}{l}8 \cdot 17 \\
7 \cdot 91\end{array}$ & $\begin{array}{l}8 \cdot 16 \\
7 \cdot 83\end{array}$ & $\begin{array}{l}8 \cdot 91 \\
7 \cdot 79\end{array}$ & $\begin{array}{l}11 \cdot 98 \\
11 \cdot 29\end{array}$ & $\begin{array}{r}7 \cdot 21 \\
3 \cdot 49\end{array}$ & $\begin{array}{l}100 \cdot 00 \\
100 \cdot 00\end{array}$ & $\begin{array}{l}549 \\
549\end{array}$ & $\begin{array}{r}10 \cdot 02 \\
9 \cdot 70\end{array}$ \\
\hline $\begin{array}{l}\text { Amoebic } \\
\text { dysentery }\end{array}$ & $\begin{array}{l}\mathbf{A} \\
\mathbf{B}\end{array}$ & $\begin{array}{l}5 \cdot 83 \\
9 \cdot 59\end{array}$ & $\begin{array}{r}9.91 \\
9 \cdot 50\end{array}$ & $\begin{array}{l}10 \cdot 60 \\
11 \cdot 35\end{array}$ & $\begin{array}{r}9.88 \\
10 \cdot 65\end{array}$ & $\begin{array}{l}10 \cdot 30 \\
11 \cdot 26\end{array}$ & $\begin{array}{l}8 \cdot 52 \\
9 \cdot 15\end{array}$ & $\begin{array}{l}8 \cdot 47 \\
9 \cdot 02\end{array}$ & $\begin{array}{l}11.03 \\
10.68\end{array}$ & $\begin{array}{l}10 \cdot 13 \\
10 \cdot 57\end{array}$ & $\begin{array}{r}15 \cdot 34 \\
8 \cdot 23\end{array}$ & $\begin{array}{l}100 \cdot 00 \\
100 \cdot 00\end{array}$ & $\begin{array}{l}1,501 \\
1,501\end{array}$ & $\begin{array}{r}9.59 \\
10.29\end{array}$ \\
\hline Typhoid & $\begin{array}{l}\mathbf{A} \\
\mathbf{B}\end{array}$ & \begin{tabular}{l|l|}
$12 \cdot 79$ & \\
$18 \cdot 76$ &
\end{tabular} & $\begin{array}{l}14 \cdot 29 \\
12 \cdot 20\end{array}$ & $\begin{array}{l}12 \cdot 28 \\
11 \cdot 72\end{array}$ & $\begin{array}{l}12 \cdot 63 \\
12 \cdot 14\end{array}$ & $\begin{array}{l}10 \cdot 64 \\
10 \cdot 37\end{array}$ & $\begin{array}{l}8 \cdot 41 \\
8 \cdot 04\end{array}$ & \begin{tabular}{|l|}
$13 \cdot 42$ \\
$12 \cdot 73$
\end{tabular} & $\begin{array}{l}6 \cdot 39 \\
5 \cdot 51\end{array}$ & $\begin{array}{l}9 \cdot 16 \\
8 \cdot 52\end{array}$ & - & $\begin{array}{l}100 \cdot 00 \\
100 \cdot 00\end{array}$ & $\begin{array}{l}244 \\
244\end{array}$ & $\begin{array}{l}11 \cdot 96 \\
11 \cdot 44\end{array}$ \\
\hline $\begin{array}{l}\text { Sandfly } \\
\text { fever }\end{array}$ & $\begin{array}{l}\mathbf{A} \\
\mathbf{B}\end{array}$ & \begin{tabular}{l|l|}
$11 \cdot 47$ \\
$17 \cdot 55$
\end{tabular} & $\begin{array}{l}15 \cdot 98 \\
14 \cdot 26\end{array}$ & $\begin{array}{l}12 \cdot 25 \\
12 \cdot 21\end{array}$ & \begin{tabular}{|l|}
$11 \cdot 37$ \\
$11 \cdot 42$
\end{tabular} & $\begin{array}{l}10 \cdot 29 \\
10 \cdot 48\end{array}$ & $\begin{array}{l}8 \cdot 03 \\
8 \cdot 02\end{array}$ & $\begin{array}{l}8 \cdot 53 \\
8 \cdot 45\end{array}$ & $\begin{array}{l}8 \cdot 53 \\
7 \cdot 70\end{array}$ & $\begin{array}{l}6 \cdot 60 \\
6 \cdot 43\end{array}$ & $\begin{array}{l}6 \cdot 95 \\
3 \cdot 47\end{array}$ & $\begin{array}{l}100 \cdot 00 \\
100 \cdot 00\end{array}$ & $\begin{array}{l}8,527 \\
8,527\end{array}$ & $\begin{array}{l}11.59 \\
11 \cdot 58\end{array}$ \\
\hline $\begin{array}{l}\text { Leishmaniasi } \\
\text { cutaneous }\end{array}$ & $\begin{array}{l}\text { is } \\
\mathbf{A} \\
\mathbf{B}\end{array}$ & $\begin{array}{l}11 \cdot 59 \\
17 \cdot 18\end{array}$ & \begin{tabular}{|l|}
$18 \cdot 78$ \\
$16 \cdot 21$
\end{tabular} & $\begin{array}{l}13 \cdot 61 \\
13 \cdot 15\end{array}$ & \begin{tabular}{|l|}
$14 \cdot 38$ \\
$13 \cdot 98$
\end{tabular} & $\begin{array}{l}11 \cdot 71 \\
11 \cdot 56\end{array}$ & $\begin{array}{l}9 \cdot 95 \\
9 \cdot 63\end{array}$ & $\begin{array}{l}9 \cdot 79 \\
9 \cdot 39\end{array}$ & $\begin{array}{r}10 \cdot 19 \\
8 \cdot 90\end{array}$ & 二 & - & \begin{tabular}{|l|}
$100 \cdot 00$ \\
$100 \cdot 00$
\end{tabular} & $\begin{array}{l}256 \\
256\end{array}$ & $\begin{array}{l}13 \cdot 37 \\
12 \cdot 94\end{array}$ \\
\hline Keratitis & $\begin{array}{l}\mathbf{A} \\
\mathbf{B}\end{array}$ & $\begin{array}{r}8 \cdot 01 \\
12 \cdot 99\end{array}$ & $\begin{array}{r}10 \cdot 26 \\
9 \cdot 70\end{array}$ & $\begin{array}{l}9 \cdot 09 \\
9 \cdot 61\end{array}$ & $\left|\begin{array}{l}10 \cdot 40 \\
11 \cdot 07\end{array}\right|$ & $\begin{array}{r}9 \cdot 50 \\
10 \cdot 25\end{array}$ & $\begin{array}{l}9 \cdot 26 \\
9 \cdot 81\end{array}$ & $\begin{array}{r}9 \cdot 77 \\
10 \cdot 25\end{array}$ & $\begin{array}{l}9 \cdot 99 \\
9 \cdot 55\end{array}$ & $\begin{array}{l}8 \cdot 35 \\
8 \cdot 60\end{array}$ & $\begin{array}{r}15 \cdot 38 \\
8 \cdot 15\end{array}$ & $\begin{array}{l}100 \cdot 00 \\
100 \cdot 00\end{array}$ & $\begin{array}{l}752 \\
752\end{array}$ & $\begin{array}{r}9 \cdot 61 \\
10 \cdot 18\end{array}$ \\
\hline $\begin{array}{l}\text { Conjuncti- } \\
\text { vitis }\end{array}$ & $\begin{array}{l}\mathbf{A} \\
\mathbf{B}\end{array}$ & $\begin{array}{r}8 \cdot 62 \\
14 \cdot 25\end{array}$ & $\begin{array}{l}10 \cdot 44 \\
10.05\end{array}$ & $\begin{array}{l}8 \cdot 79 \\
9 \cdot 47\end{array}$ & $\begin{array}{l}7 \cdot 58 \\
8 \cdot 22\end{array}$ & $\begin{array}{l}8 \cdot 24 \\
9 \cdot 06\end{array}$ & $\begin{array}{l}9 \cdot 05 \\
9 \cdot 76\end{array}$ & $\begin{array}{l}8 \cdot 82 \\
9 \cdot 43\end{array}$ & $\begin{array}{r}10 \cdot 22 \\
9.95\end{array}$ & $\begin{array}{l}8 \cdot 99 \\
9 \cdot 44\end{array}$ & $\begin{array}{l}19 \cdot 25 \\
10 \cdot 38\end{array}$ & $\begin{array}{l}100 \cdot 00 \\
100 \cdot 00\end{array}$ & $\begin{array}{l}1,107 \\
1,107\end{array}$ & $\begin{array}{l}8.91 \\
9.61\end{array}$ \\
\hline $\begin{array}{c}\text { Cystitis and } \\
\text { pyelitis }\end{array}$ & $\begin{array}{l}\mathbf{A} \\
\mathbf{B}\end{array}$ & $\begin{array}{l}5 \cdot 59 \\
9 \cdot 12\end{array}$ & $\begin{array}{r}10.45 \\
9.94\end{array}$ & $\begin{array}{l}9 \cdot 39 \\
9 \cdot 99\end{array}$ & \begin{tabular}{|l|}
$10 \cdot 21$ \\
10.93
\end{tabular} & $\begin{array}{r}9 \cdot 68 \\
10 \cdot 51\end{array}$ & $\begin{array}{l}7 \cdot 67 \\
8 \cdot 17\end{array}$ & \begin{tabular}{|l|}
$12 \cdot 32$ \\
$13 \cdot 01$
\end{tabular} & $\begin{array}{l}13.94 \\
13.41\end{array}$ & $\begin{array}{l}7 \cdot 65 \\
7 \cdot 94\end{array}$ & $\begin{array}{r}13 \cdot 11 \\
6 \cdot 98\end{array}$ & $\begin{array}{l}100 \cdot 00 \\
100 \cdot 00\end{array}$ & $\begin{array}{l}586 \\
586\end{array}$ & $\begin{array}{r}9 \cdot 64 \\
10 \cdot 27\end{array}$ \\
\hline
\end{tabular}

war, any estimate of basic strength data is specially liable to error in the two age groups at the extremes of the range, viz. under 22 and over 45 . Consequently, it would be foolish to attach any signal importance to features characteristic of the limiting fringes of the distribution. With respect to any legitimate conclusions we may base on such estimates, it is also necessary to take stock of other circumstances:

. (a) infantry, being more exposed to conditions where preventive measures are least effective, is the arm of the service with a concentration of the younger age groups; 
(b) the youngest age group is presumptively the group with the shortest mean period of overseas service, and hence the one least liable to previous exposure to risk;

(c) the over $\mathbf{4 5}$ age group is likely to have:

(i) a relatively high concentration in static units where risk of disease is at a minimum;

(ii) an abnormally high proportion of regular soldiers who have been previously exposed to infections not prevalent in the United Kingdom;

(iii) a make-up resulting from especially vigorous selection with reference to physique or general health.

For all these reasons we should discount: (a) any minor trends with respect to susceptibility as age increases; (b) any conclusions referable to the oldest or youngest age group. Figures for the oldest age group in Table XVI refer in all cases to a very small sub-sample, and are hence liable to gross sampling error as well as to errors arising from circumstances stated above. With one possible exception, i.e. Flexner's dysentery, it is noteworthy that no disease included in this table displays a conspicuously steep trend comparable with what is so characteristic of communicable diseases in the United Kingdom. Though we have no means of assessing precisely the incidence of the Flexner type in the United Kingdom, clinical experience suggests that it is not uncommon in institutions; and its occurrence in the civilian population may well be more extensive than one commonly supposes. In any case, there are good grounds for believing that it is less rare than typhoid. These distributions are admittedly imperfect for a variety of reasons stressed above. With due recognition of their imperfections the conclusion to which we are led is consistent with the hypothesis previously advanced to account for declining incidence of communicable diseases as age advances. It is unfortunate that available statistics with reference to Colonial troops do not include basic demographic data to elucidate the complementary issue, i.e. whether a population exposed to risk in early youth would present a totally different picture.

\section{Significance of Age in Relation to Immunity}

We have seen that: $(a)$ age-specific rates for non-communicable diseases usually go up as age advances; (b) age-specific rates for communicable diseases usually go down. We have also discussed certain exceptions to these rules vis d vis reduction of the effective population at risk by immunization. It is not unprofitable to scrutinize the quantitative implications of this hypothesis in greater detail. In conformity with symbols used elsewhere, we suppose that there are $C_{x}$ cases of a disease in a population containing $P_{x}$ individuals of the same $(x$ th) age group, so that the incidence in the $x$ th age group is $I_{x}=C_{x} \div P_{x}$. We also specify the corresponding effective (non-immune) population at risk as $S_{x}$, being less than $P_{x}$; and the effective incidence which measures the true liability of an $x$-year-old to contract 
the disease as $E_{x}=C_{x} \div S_{x}$. The size of the population in successive age groups is irrelevant to our purpose. We can therefore restrict our population to a standard one of age groups of equal size, putting $P_{x}=P_{x+1}$, etc.

The simplest form our hypothesis may take is that the true liability $E_{x}$ to contract a non-fatal disease is not affected by age, i.e. diminishing incidence as age advances is wholly attributable to immunization. Accordingly $E_{x+1}=k=E_{x}$. We may first assume that immunization to. a single attack is complete, so that:

$$
\begin{aligned}
& S_{x+1}=S_{x}-C_{x} \\
& \therefore C_{x+1}=E_{x+1}\left(S_{x}-C_{x}\right) \\
& =E_{x}\left(S_{x}-C_{x}\right) \\
& =E_{x} S_{x}-E_{x} C_{x} \\
& =C_{x}-E_{x} C_{x} \\
& \therefore \Delta \mathrm{C}_{\mathrm{x}}=-\mathrm{E}_{\mathrm{x}} \mathrm{C}_{\mathrm{x}} \\
& =-\mathbf{k C}_{\mathbf{x}} \\
& \Delta I_{x}=-k I_{x}
\end{aligned}
$$

Since $I_{x}=C_{x} \div P_{x}$ and $I_{x+1}=C_{x+1} \div P_{x}$ :

This is the difference equation of a geometric series of which the general formula is:

$$
I_{x}=I_{o}(1-k)^{x}
$$

Within the framework of our first set of assumptions, the hypothesis stated therefore implies an exponential law of declining incidence. Within the army age group this accords with the picture disclosed by our data (Table VIII) of such diseases as : Chicken pox, Measles, Rubella, Diphtheria, Mumps, Scarlet fever, Impetigo, Glandular fever, Infective hepatitis.

If immunization is incomplete, i.e. if a previous infection fails to protect a certain proportion of individuals from a subsequent manifest attack, the only necessary qualification to the preceding argument is that previous attack removes a fraction $m(<1)$ of cases from the effective population at risk in the $x$ th year of life, so that:

If we put $\mathrm{K}=\mathrm{m} \cdot \mathrm{k}$

$$
\begin{aligned}
S_{x+1} & =S_{x}-m \cdot C_{x} \\
\therefore \triangle \Delta I_{x} & =-m \cdot k \cdot I_{x}
\end{aligned}
$$

$$
I_{x}=I_{o}(1-K)^{x}
$$

Since $m<1, K<k$ and the only effect of the change of constant is to make the graph of $I_{x}$ in (ii) less steep than that of $I_{x}$ in (i).

The preceding treatment postulates that the disease is not fatal. If it is more or less fatal, we have to introduce a survival rate formally analogous to $m$ also $<1$, and the effect of doing so is merely to reduce the rate of declining incidence. Clearly its slope would be zero if the survival rate were zero.

Within the compass of the foregoing assumptions, we can provide for more or less steep decline of incidence which we can represent by an exponential function with a line parallel to the $\mathrm{x}$-axis as the limiting case; but we cannot account for a secondary nor for an initial rise without recourse to other postulates. It is reasonable to assume that what we have here called the true liability $\mathrm{E}_{\mathrm{x}}$ is not 
constant, increasing with age as it does for most diseases which are not communicable. The functional relation we chose is necessarily arbitrary, but for various reasons we can take as sufficiently generalized:

$$
\mathrm{E}_{\mathrm{x}}=\mathrm{E}_{\mathrm{o}} \mathrm{a}^{\mathrm{x}} \text { and } \mathrm{E}_{\mathrm{x}+1}=\mathrm{aE}_{\mathrm{x}}
$$

The new hypothesis implies that the constant $a$ in the above is greater than unity. As before we put:

$$
\begin{aligned}
C_{x+1} & =E_{x+1}\left(S_{x}-C_{x}\right) \\
& =\left(a-E_{o} a^{x+1}\right) C_{x} \\
\therefore I_{x+1} & =\left(a-E_{o} a^{x+1}\right) I_{x} \\
\therefore \triangle \triangle I_{x} & =\left(a-1-E_{0} a^{x+1}\right) I_{x}
\end{aligned}
$$

A solution of the above is:

$$
I_{x}=I_{0} \cdot \prod_{r=1}^{r-x}\left(a-E_{0} a^{r}\right)
$$

From the form of (iii) it is evident that $\mathrm{I}_{\mathrm{x}}$ increases as $x$ increases when $\left(\mathrm{a}-\mathrm{E}_{\mathrm{o}} \mathrm{a}^{\mathrm{x}+1}\right)$ is greater than unity, diminishes when $\left(a-E_{o} a^{x+1}\right)$ is less than unity, and undergoes no change when

$$
\begin{aligned}
a-E_{o} a^{x+1} & =1 \\
x \quad & =\log _{a} \frac{a-1}{a E_{o}}
\end{aligned}
$$

By hypothesis, $a>1>E_{o}$ and both constants are positive. With these limitations the factor $\left(\mathrm{a}-\mathrm{E}_{\mathrm{o}} \mathrm{a}^{\mathrm{x}+1}\right)$ must decrease as $x$ increases; but it may exceed unity at the start. In other words $I_{x}$ may initially increase to a maximum defined by (vi) and subsequently diminish. It cannot at first decrease and subsequently increase. Within the framework of approximations inherent in the derivation of the preceding difference equations, the hypothesis that the trend of incidence is the outcome of interplay between immunization and increasing liability is thus consistent with the possibility of an initial rise followed by a fall, as is true of phthisis in the Army age range, but would not appear to allow for an initial decline with a subsequent rise. If immunity is incomplete in the sense defined above or if the disease is partially fatal, we have to introduce a factor $m$ as before. The corresponding difference equation is:

The maximum value is then given by:

$$
I_{x}=a^{x} I_{o} \prod_{r=0}^{r-x-1}\left(1-m E_{o} a^{r}\right)
$$

$$
x=\log _{a} \frac{a-1}{a m E_{o}}
$$

As before, $\mathrm{a}>1, \mathrm{E}_{\mathrm{o}}$ and $m$ both $<1$. The preceding remarks therefore hold good.

We have not, however, examined the consequences of imposing the limitation that immunity is temporary, persisting over a period of $n$ age-units. If we postulate a fixed liability $k$ as in (i) above and proceed as before, we arrive at the difference equation:

$$
I_{x+1}=(1-k) I_{x}+k . I_{x-n}
$$

This reduces to a simple algebraic formula for the general term, when $n=1$, i.e. immunity persisting for 1 year if we reckon age $(x)$ by years; but it is simple to 
build up the corresponding series by assuming particular values of $k$ or $n$ when $n>1$. In any case, we can choose our age unit to tally with the period of immunity conferred if the latter is relatively short in terms of the whole span of life. The above then reduces to a linear difference equation of the second order, i.e. to the form:

$$
I_{x+2}+(k-1) I_{x+1}-k I_{x}=0
$$

The standard solution of this defines a recurrent series being:

$$
(1+k) I_{x}=\left(k I_{o}+I_{1}\right)+\left(I_{o}-I_{1}\right) \cdot(-k)^{x}
$$

Values of $\mathrm{I}_{\mathrm{x}}$ decrease as $x$ increases with a highly damped periodicity approaching a positive limit. Since $k=\mathrm{I}_{\mathrm{o}}$ by definition, the limit is given by:

$$
I_{x}=\left(I_{o}^{2}+I_{1}\right) \div\left(1+I_{o}\right)
$$

By introducing the postulate of temporary immunity, we thus arrive at the difference equation of a function whose numerical properties are consistent with an initial fall and subsequent rise as is characteristic of lobar pneumonia in the Army age range. A comprehensive and more exact analysis of the issue therefore offers the hope of defining a precise statistical criterion to assess the validity of the assumption that a single attack of a disease confers permanent immunity.

\section{CONCLUSION}

The foregoing exposition has brought into focus two main issues. One is a dichotomy between two categories of disease which we may respectively distinguish as communicable and progressive. The significance of this broad distinction with respect to the relation of age to disease risk has been the subject of detailed treatment in section 7; and there is no need to traverse a second time the issues there discussed, nor to restate the provisional hypothesis advanced. Another facet of the relation between age and morbidity risk directs our attention to what medical problems in one or other age group of the population have more or less priority vis $a$ vis allocation of specialist man-power and the claims of research within the framework of a National Health Service. That the urgent medical problems of the youngest and oldest age groups in the population are peculiar is a commonplace; but the extent to which the occurrence of particular diseases depends on the age composition of a community has hitherto received little attention. It is one which clearly deserves closer scrutiny àgainst the background of researches, such as those of Enid Charles and others, whose work has emphasized the prospect of a very considerable shift in the age composition of our own population. Such a shift calls for a readjustment of our views concerning the relative magnitude of different diseases as matters of concern to the community as a whole. At present, the social machinery of medicine outside the armed Services does not permit a direct attack upon this problem en rapport with that of the present inquiry; but it should be possible to follow up clues suggested by morbidity experience within the Army age group by recourse to field inquiries employing sampling methods.

We wish to acknowledge helpful suggestions from Dr. A. P. Thomson, Dr. Enid Charles and Lt.-Col. James who read the proofs of this paper. 